\title{
Specialization in the presence of trade and financial openness
}

\author{
Jaap W. B. Bos ${ }^{1} \cdot$ Claire Economidou ${ }^{2} \cdot$ Lu Zhang $^{3}$
}

Received: 30 March 2016 / Accepted: 10 December 2018 / Published online: 5 March 2019

(c) The Author(s) 2019

\begin{abstract}
This paper sheds new light on the relationship between openness and industrial specialization. The roles of trade and financial openness, separately and in conjunction with each other, are unraveled to study specialization patterns for a panel of 30 countries for more than three decades. Results show that trade openness has a stronger association with industrial specialization in countries with a low degree of intra-industry trade, whereas financial openness has a stronger association with specialization in countries with more developed financial systems. Further, the effect of trade (financial) openness on specialization is enhanced by the level of financial (trade) openness.
\end{abstract}

Keywords Specialization $\cdot$ Trade openness $\cdot$ Financial openness $\cdot$ Manufacturing JEL Classification C23 $\cdot$ F14 $\cdot$ F15 $\cdot$ G29 $\cdot$ L60

\footnotetext{
We are grateful to Angelos Kanas, Clemens Kool, Sebnem Kalemli-Ozcan, Emmanuel Mamatzakis, Mark Sanders and Bent Sörensen for helpful comments and discussions. Lu Zhang gratefully acknowledges the financial support from Netherlands Organization for Scientific Research (NWO). The usual disclaimer applies.

Lu Zhang

l.zhang@cpb.nl

Jaap W. B. Bos

j.bos@maastrichtuniversity.nl

Claire Economidou

economidou@unipi.gr

1 School of Business and Economics, Maastricht University, 6200 MD Maastricht, The Netherlands

2 Department of Economics, University of Piraeus, 18435 Piraeus, Greece

3 CPB Netherlands Bureau for Economic Policy Analysis, Bezuidenhoutseweg 30, 2594 AV The Hague, The Netherlands
} 


\section{Introduction}

The past few decades have witnessed an accelerated pace of economic integration, reflected by a very rapid growth in cross-border commercial trade and capital flows. ${ }^{1}$ Trade and capital flows have increased dramatically during the last decades, as shown in Fig. 1a. As a result, financial assets and liabilities have shown a threefold increase since the early 1990s. ${ }^{2}$ At the same time, industrial specialization-the domination of economies by a limited number of industries-has steadily increased since 1985, as shown in Fig. 1 b.

The reduction or, in some cases, complete elimination of trade and financial barriers has significantly reduced the costs of international transactions. The resulting enhanced mobility of production factors has facilitated the re-location of production across sectors and geographical spaces. The recent increases in specialization suggest that the effect of trade and financial openness has been a reorientation of most economies towards a more concentrated industry structure.

An interesting question that arises is what are the linkages between openness and industrial specialization? Increased specialization is desirable, as it enhances efficiency and competitiveness of a country and consequently has significant welfare implications (Eckel 2008). ${ }^{3}$ However, countries with specialized production structures are more vulnerable to asymmetric shocks - an issue of particular importance for monetary union country members. Trade and financial openness can both shape the dynamics of industrial specialization, creating potentially more (a)symmetric responses to the presence of a shock. Financial openness, for example, may contribute to industrial specialization, as firms can borrow from abroad to differentiate their production, but it also facilitates better risk sharing opportunities, as the borrowing risk is shared across different countries. ${ }^{4}$ Therefore, understanding the nature of the relationship between economic integration and industrial specialization is important, both for economists and policy makers.

So far, the literature has typically studied the roles of trade and financial openness in isolation. A large strand of the literature has explored the relationship between trade openness and specialization. Early trade theories predict that the reduction of trade costs tends to increase inter-industry trade, i.e., trade of goods across industries. The main argument is that the former facilitates the way countries exploit comparative advantages due to cross-country differences in technology or factor endowment (Ricardo 1817; Ohlin 1933), which in turn results in divergence of production structures across countries. New trade theories (Krugman 1979, 1980; Krugman and

\footnotetext{
${ }^{1}$ In this paper, as we measure trade and financial integration by means of de facto openness, we use the terms "integration" and "openness" interchangeably.

2 Authors' calculations for the sample period, 1970-2011.

3 According to Eckel (2008), if specialization falls and the losses from specialization are large, compared to gains from increases in firm size due to globalization, the per capita output can decrease and welfare can actually decline.

4 A number of studies, for example, Greenwood and Jovanovic (1990), Saint-Paul (1992), and Acemoglu and Zilibotti (1997) have investigated the impact of insurance-induced specialization on economic growth and development.
} 
(a) Development of trade and financial openness

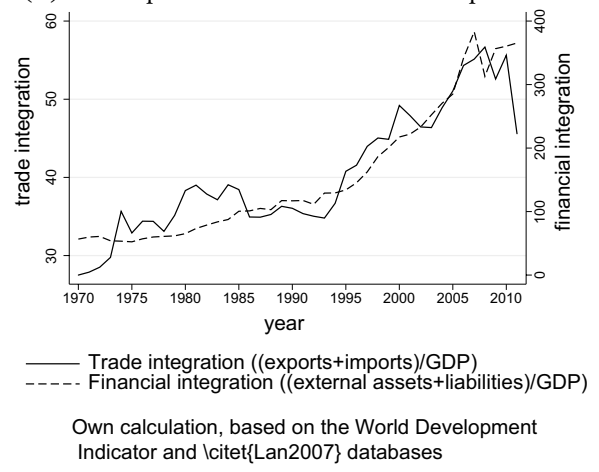

(b) Development of industrial specialization

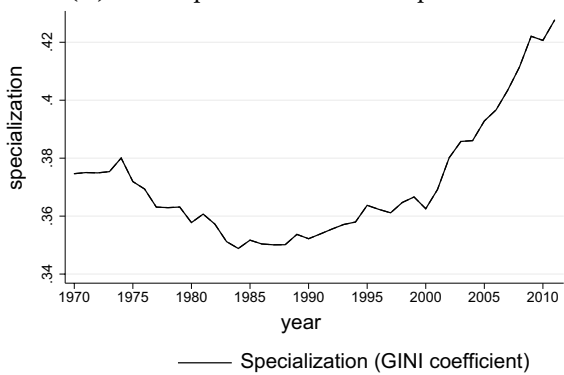

GINI coefficient calculated using value added industry data from EU KLEMS, WIOD and OECD databases.

Fig. 1 Developments in openness and specialization. Note: Both graphs are weighed by the country size, based on authors' own calculations from a sample of 31 countries, see Table 4 in the "Appendix"

Venables 1990), however, stress the importance of increasing returns to scale and product differentiation in facilitating intra-industry trade, i.e., trade of goods across countries that belong to the same industry. As a result, these theories predict that trade integration will induce a shift of increasing-return industries towards countries with good market access ("the core"), i.e., the home market effect. Theories of new economic geography (Krugman 1991; Venables 1996) emphasize spatial agglomeration forces in shaping specialization patterns and suggest a non-monotonic relationship between trade liberalization and location of economic activities, depending on the level of trade costs. ${ }^{5}$

A separate and smaller strand of literature investigates the relationship between financial openness and industrial specialization. This literature argues that with financial openness countries are better-protected against idiosyncratic risks and consequently can specialize more. ${ }^{6}$ The seminal study of Kalemli-Ozcan et al. (2003) investigates the relationship between risk sharing from financial openness and production specialization. The authors find a positive and robust link between risk sharing and specialization among regions in the USA, as well as across some OECD countries. Basile and Girardi (2010) use more advanced estimation methods, allowing for non-linearity and spatial dependence, and confirm a similar positive relationship across European regions. Although Kalemli-Ozcan et al. (2003) acknowledge

\footnotetext{
5 In the presence of high trade costs, industry structures remain unaltered, whereas the reduction of trade costs results in the agglomeration of economic activities into fewer locations. When trade costs drop below a threshold, these agglomerations become smaller and more dispersed across space.

6 A related literature investigates risk sharing patterns across countries. For example, Artis and Hoffmann (2007) and Sorensen et al. (2007) find improved risk sharing among industrialized countries as financial openness increases. Other studies find little evidence of improved risk sharing, despite massive financial openness (Moser et al. 2004; Bai and Zhang 2006). See Kose et al. (2009b) for an extensive literature survey. Obstfeld (1994) shows that financial market integration provides insurance through a globally diversified portfolio of investments, thereby encouraging countries to simultaneously shift from low-return, safe investments toward high-return, risky investments promoting higher growth.
} 
and control for the potential impact of trade openness on specialization, the effect of trade openness in conjunction with financial integration as joint determinants of specialization is not explicitly examined in both studies. ${ }^{7}$

The purpose of this paper is to investigate the relationship between openness and industrial specialization in a comprehensive manner for a large set of countries using a detailed sample of manufacturing industries. Our sample consists of 20 manufacturing industries in 30 countries over the period 1970-2011.

More particular, the paper aims to answer two important questions. The first, and most basic question, is how does openness relate to industrial specialization? To answer this question, we first consider two separate channels of openness, trade and financial openness, and examine their relationship with production specialization. Next, we find out whether trade-induced specialization is less prevalent if intraindustry trade dominates, as specialization in the latter case occurs mainly within the same industry (Krugman 1980). Finally, we investigate whether the relationship between financial openness and specialization is stronger in countries with more developed financial systems (Masten et al. 2008).

The second question we ask is to what extent trade and financial openness complement each other in shaping industrial specialization. To answer this question, we examine the relationship between trade (financial) openness on specialization, conditional on the level of financial (trade) openness. In doing so, we also explore whether the composition of financial flows matters, i.e. the relative shares of portfolio equity, foreign direct investment (FDI) and external debt. Portfolio equity and FDI flows are perceived to be more conductive to risk sharing (Kose et al. 2009b), whereas debt flows are more prone to sudden stops, triggering economic crises. Thus, it would be desirable for (emerging) countries to reduce their reliance on debt finance and increase the importance of equity and FDI finances (Rogoff 1999). We use various instruments for both openness measures and appropriate econometric techniques to enhance robustness of our results, explore threshold effects and to avoid endogeneity problems.

Our work relates to various strands of literature. We contribute to the literature that explores the patterns of industrial structures across countries and infers whether changes of patterns reflect ongoing economic integration (Krugman 1991; Sapir 1996; Brülhart 2001; Longhi et al. 2003; Riet et al. 2004). In this literature, trade and financial integration are mostly latent, at best, captured by a linear time trend (Longhi et al. 2003). Our paper explicitly considers the roles of trade and financial openness, allowing for interaction between both channels.

We also contribute to a number of recent studies that investigate the dynamic impact of trade openness on specialization patterns. For instance, Beine and Coulombe (2007) study the impact of trade liberalization between Canada and the USA, measured by the decrease in trade-weighted tariffs, on the degree of industrial specialization for Canadian regions. Their results favor a positive short-run relationship and a negative long-run relationship between trade integration and industrial specialization, i.e., short-run specialization and long-run diversification. Crabbé et al.

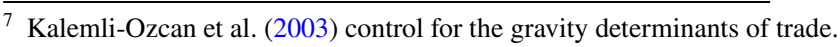


(2007) perform a similar analysis for thirteen CEEC countries and show that trade integration leads to long-run specialization. ${ }^{8}$ An important element missing in all aforementioned papers is financial openness, which is explicitly taken into account here.

We further relate to a handful of studies that have attempted to unify different strands of literature to analyze the effect of trade and financial openness on specialization. For example, the study of Imbs (2004) examines the complex relationships between trade, finance, specialization and business cycle synchronization in the context of a system of simultaneous equations based on a cross-sectional country-pair setting in 24 countries. $^{9}$

Our paper builds on these earlier contributions, mainly on Imbs (2004) and Kalemli-Ozcan et al. (2003, 2004). In contrast to those papers, this paper treats trade and financial openness as multilateral rather than bilateral phenomena (Imbs 2006), thus chooses country-year instead of country-pair as the unit of our analysis, and discusses the complementarity of trade and financial openness as channels of specialization. The panel-based estimation techniques used here exploit both timeseries as well as cross-section variations and are well suited to solve endogeneity issues, thus yielding more efficient estimates. The empirical analysis is based on a sample that consists of manufacturing industries, twice as disaggregated as those used in past related studies (Kalemli-Ozcan et al. 2003), and a time span that is more extensive than that of previous studies (Imbs 2004; Basile and Girardi 2010).

Our results reveal that financial openness, to a less extent trade openness, has a positive relationship with specialization (Kalemli-Ozcan et al. 2003; Basile and Girardi 2010; Imbs 2004). Whereas intra-industry trade lowers the impact of trade openness on specialization, financial development strengthens the effect of financial openness on specialization.

In addition, we find that both channels of openness enhance each other. In particular, we find that the positive relationship between financial openness and specialization only exists when countries are sufficiently open to trade. This finding extends and complements those of Imbs (2004). Furthermore, portfolio equity, FDI and debt are all useful instruments for attaining the risk sharing benefits associated with financial openness, consequently inducing specialization. These results are robust to alternative model specifications and the use of a range of different measures of openness and specialization.

Our findings highlight that policies for (further) trade and financial integration should be jointly designed for countries to fully seize the benefits of specialized production structures, economies of scale and increased efficiency. However, countries with specialized production structures are more vulnerable to asymmetric shocks.

\footnotetext{
${ }^{8}$ Crabbé et al. (2007) interpret the different results as evidence of a possible non-monotonic relationship between trade integration and industrial specialization along the development path. A closely related study in this respect is that of Imbs and Wacziarg (2003), who demonstrate a U-shaped pattern between the specialization of a country and the level of its per capita income. Countries initially diversify to reduce the risk of sector-specific shocks, while in the later stage of development, countries start to specialize when their per capita income has grown to a critical level.

9 Similar investigations are performed by Frankel and Rose (1998), Kalemli-Ozcan et al. (2004), Imbs (2006), Calderón et al. (2007), Inklaar et al. (2008).
} 
The latter is of particular interest for the Eurozone, where well-functioning risksharing mechanisms can secure the benefits of specialization.

The remainder of the paper proceeds as follows. Section 2 exposes the model(s) under estimation and the econometric strategy. Section 3 presents the data and the measures proposed. Section 4 discusses the results. Finally, Sect. 5 summarizes and concludes.

\section{Methodology}

This section presents the empirical specifications and discusses the estimation strategies followed.

\subsection{Model specification and theoretical considerations}

To answer our first question, regarding the (independent) effects of trade and financial openness on specialization of production, we start with the following specification: ${ }^{10}$

$$
S_{i t}=\mu_{i}+\beta_{1} T_{i t}+\beta_{2} F_{i t}+\beta^{\prime} Z_{i t}+\varepsilon_{i t},
$$

where $i$ denotes the country and $t$ time; $S$ is a specialization index; $\mu_{i}$ is countryspecific fixed effect; $T$ and $F$ capture the degree of trade and financial openness, respectively; $\beta^{\prime}$ is a $1 \times n$ parameter vector; $Z$ is an $n \times 1$ vector of control variables; and, finally, $\varepsilon_{i t}$ is the error term. All variables are in logs. ${ }^{11}$

Most classical trade theories, with reference to the theory of comparative advantage, predict that trade openness leads to more industrial specialization and accordingly we expect a positive $\beta_{1}$. Falling trade costs result in a narrowing non-traded sector, and therefore it is cheaper to import goods rather than produce them domestically (Dornbusch et al. 1977). Thus, resources are freed up and used more intensely in fewer activities.

Financial openness may induce specialization through risk-sharing. Open and integrated financial markets offer a broader range of financial instruments and permit the diversification of ownership via two types of insurance. First, if residents in one country hold debt and equity claims on the output of the other country, then the dividend, interest and rental income derived from these holdings contribute to smoothing the effects of output shocks across countries. It is thus a form of ex ante international insurance. Second, to achieve consumption smoothing, households in each country can ex post adjust their asset portfolios, following the occurrence of shocks in the region. Again, this will lead to income smoothing in all countries. Once insurance is available through trade in financial assets, each country will have

\footnotetext{
10 See, for example, Kalemli-Ozcan et al. (2003), Basile and Girardi (2010).

11 There is no theoretical guidance on whether to use levels or logs of variables in our specifications. Ultimately, we choose logs as they yield a better fit and make the results easier to interpret as elasticities. See, for example, Baltagi et al (2009) for a similar treatment regarding the functional form.
} 
a stronger incentive to specialize in fewer forms of production (or technology) in order to fully exploit economies of scale or technological competitive advantages. Therefore, $\beta_{2}$ is expected to carry a positive sign (Kalemli-Ozcan et al. 2003; Basile and Girardi 2010).

The vector $Z$ contains a number of control variables that have been commonly used in the relevant literature. These variables capture the country size and the stage of its economic development. More specifically, country size is measured by population. A large country may foster a broader range of industrial productions and thus has a more balanced industrial structure, whereas the opposite could be the case for a small country. Consequently, the coefficient for country size is expected to bear a positive sign, as small countries are more likely to specialize. The stage of economic development is measured as GDP per capita, and the square of GDP per capita to allow for possible nonlinear effects between economic development and specialization. For instance, Imbs and Wacziarg (2003) argue that specialization is likely to change along the development path of a country. They provide robust evidence that countries experience two stages of diversification. At low levels of per capita income, countries reduce their overall specialization to mitigate the adverse effect of sector-specific shocks, while when per capita income reaches a high level, countries specialize again to fully exploit the comparative advantage. ${ }^{12}$

Recent evidence (e.g. Kose et al. 2006, 2009a) has demonstrated that trade and financial openness are closely related phenomena as they tend to move closely together and countries often cannot opt for trade (financial) integration independently of their degree of financial (trade) integration.

Therefore, to address our second question, which is to what extent financial (trade) openness acts as a moderator to the effect of trade (financial) openness on specialization, we introduce an interaction term $(T \times F)$ :

$$
S_{i t}=\mu_{i}+\beta_{1} T_{i t}+\beta_{2} F_{i t}+\beta_{3} T_{i t} \times F_{i t}+\beta^{\prime} Z_{i t}+\varepsilon_{i t} .
$$

In Eq. (2a), we allow the relationship of one type of openness with specialization to be moderated by the other type of openness. The marginal effect of trade (financial) openness on specialization is now conditional on financial (trade) openness, as shown in Eqs. (2b) and (2c), respectively:

$$
\begin{aligned}
& \frac{\partial S_{i t}}{\partial T_{i t}}=\beta_{1}+\beta_{3} F_{i t}, \\
& \frac{\partial S_{i t}}{\partial F_{i t}}=\beta_{2}+\beta_{3} T_{i t} .
\end{aligned}
$$

According to classical theories of trade, international trade works as a substitute for capital flows as trade reduces the incentives for capital to flow to capital-scarce countries. However, recent theoretical and empirical evidence offers and confirms

\footnotetext{
12 From a theoretical point of view, Imbs and Wacziarg (2003) argue that this pattern is consistent with models featuring endogenous stages of specialization to both trade and economic growth.
} 
a number of reasons that support the complementarity between trade and financial openness.

On the one hand, trade openness may foster financial openness, either by creating demand for symmetric financial flows or by promoting FDI in export-oriented sectors. The rapid growth of FDI and the establishment of multinational firms further drive the demand for financing, as those firms increasingly turn to banks and the stock exchange to raise funds, thus contributing to growing financial flows. ${ }^{13}$

On the other hand, financial openness may promote specialization via risk sharing or by facilitating the reallocation of capital to sectors that have a comparative advantage, therefore increasing the opportunities for trade (Feeney 1994a, b). Antràs and Caballero (2009) model trade and capital flows as complements, especially in less financially developed economies, as trade integration increases the return to capital and capital inflows to these countries. This complementary relationship has also been confirmed empirically by a number of studies. ${ }^{14}$ In line with this literature, we expect the impact of trade (financial) openness on specialization to increase with the degree of financial (trade) openness, resulting in a positive $\beta_{3}$ in Eqs. (2b) and (2c).

\subsection{Estimation procedure}

We use the two-step GMM estimator to extract consistent and efficient estimates of the various model specifications discussed above. With the two-step GMM estimation procedure, we can control for country-specific heterogeneity, non-stationarity of variables and possible endogeneity (reverse causality) of the regressors. ${ }^{15}$ As a result, we are able to examine causal effects that most other related studies ignore. In particular, if there is reverse causality from specialization to trade and financial openness, this poses serious challenges to the validity and inferences of the estimates. For example, Imbs (2004) finds a negative relationship running from

\footnotetext{
13 For example, a number of studies show that multinational or foreign firms have easier access to international sources of external financing and face lower financing obstacles (Schiantarelli and Sembenelli 2000; Harrison and McMillan 2003; Beck et al. 2006).

14 For example, Aizenman and Noy (2009) find evidence of a two-way feedback between trade and financial integration, i.e., de facto trade (financial) openness is associated with larger future financial (trade) openness. Chambet and Gibson (2008) decompose trade openness into its natural and residual components and find that both measures contribute positively to stock market integration for a large panel of emerging economies. Chow et al. (2005) confirm the interdependence of trade and financial integration in East Asian countries. Kalemli-Ozcan and Nikolsko-Rzhevskyy (2010) confirm that trade causes capital flows, using historical evidence from trade and financial flows between three source countries (Germany, France, the UK) and one host country (the Ottoman Empire) over 1859-1913, whereas García-Herrero and Ruiz (2008) argue that trade linkages do not seem to be significantly affected by financial linkages in the country of their investigation, Spain.

15 More specifically, the two-step GMM estimator utilizes an optimal weighting matrix that minimizes the asymptotic variance of the estimator. It takes the first differences of the variables to remove unobserved country-specific effects and any endogeneity bias arising from the correlation of these fixedeffects with explanatory variables. First-differencing also ensures the stationarity of variables. Since the time dimension of our panel is relatively long, we need to adequately consider the non-stationary nature of regression variables in order to avoid running a spurious regression.
} 
specialization to trade, as a result of intra-industry trade. Similarly, financial openness is likely to be an endogenous variable based on the argument that more specialized countries demand more international insurance and are therefore more likely to engage in financial integration. We alleviate this endogeneity concern by using lagged levels to instrument the endogenous variable in the first-difference equation. Bellemare et al. (2017) postulate that researchers should be careful for using lagged explainatory variables for identification purpose. There are two situations under which lagging an explanatory variable purges the estimate of endogeneity: (1) serial correlation in endogeneous variables; (2) no serial correlation among the unobserved sources of endogeneity. Given that these conditions are unlikely to be met with certainty, for each country, we construct the average of its neighboring countries' trade (financial) openness $(A T$ and $A F$ ) as alternative instruments. These two instruments allow us to exploit the (time-varying) exogeneity of this variable to identify the effects of trade and financial integration on specialization, following Baltagi et al (2009) and alleviate the concern of exclusively relying on lagged levels as instruments, thereby ensure the the validity of the estimation results. For comparison, we also report OLS estimates.

To check the consistency of our estimates, we employ various diagnostic tests. First, we perform a Durbin-Wu-Hausman (DHW) endogeneity test in order to examine whether trade and/or financial openness is indeed endogenous in our model(s). Then, we ensure the validity of the instruments used to overcome reverse causality issues. The key exogeneity assumption in our context is that a country's historical levels of trade are orthogonal to current shocks to specialization. Therefore, lagged variables must be uncorrelated with the error term in the level equations. To see whether this assumption holds, we apply a Arellano-Bond serial correlation test. ${ }^{16}$ The usage of multiple instruments allows us to perform a Hansen test of over-identifying restrictions. Then, the Kleibergen-Paap rk test is used to examine whether the endogenous regressor is well identified by the instruments. Lastly, we employ the Anderson-Rubin weak-identification-robust test. The last two tests ensure the relevance and strength of our instruments. ${ }^{17}$

\section{Data}

In answering the questions posed in this paper, we face a number of data considerations. First, having a sufficiently disaggregated set of industries is important to avoid aggregation issues when measuring specialization. Put bluntly, at a higher level of

\footnotetext{
${ }^{16}$ If there is no serial correlation (in the level equation), one should reject the null hypothesis of absence of serial correlation in the first differences. In this case, any historical values of trade, beyond period $t-2$, are potentially valid instruments. In contrast, if serial correlation is present, one needs to take deeper lags from period $t-3$ as instruments. In principle, the number of lags available as instruments increases with the time dimension $T$. To alleviate the potential problems arising from a disproportional large number of instruments, we limit the number of lags to three. Our choice is also motivated by a practical reason that some countries are covered in our sample for a relatively short period of time. We limit the number of lags in order not to lose a significant amount of observations.

17 For a comprehensive discussion of our methodology, see Baum et al. (2003).
} 
aggregation, countries' industrial structures will appear alike by construction. A second consideration for the purpose of our analysis is the fact that we require a relatively broad set of countries to ensure sufficient variation in specialization patterns. Third, trade and financial openness are complex processes that require time to develop. ${ }^{18}$ Since reverse causality may be an issue, a long time span allows for a deeper lag structure and more appropriate instruments.

Our empirical analysis covers an unbalanced panel of 20 2-digit manufacturing industries in 30 countries during the period 1970-2011, the longest period for which data are available for the largest amount of countries. We focus on manufacturing industries on the premise that these industries, in contrast to services, are involved in trade and are therefore more responsive to trade integration.

We ensure that the number of sectors available through time is constant across countries, while coverage across time varies per country. This way, both within-country and cross-country changes in specialization can be compared and interpreted in a consistent manner. Table 4 in "Appendix A" lists the 30 countries and the corresponding time span. Table 5 in "Appendix A" reports the 20 industries and their NACE codes considered in our analysis. Annual raw data are retrieved from various sources.

Below, we present the construction of our variables and their sources.

\subsection{Industrial specialization}

Our primary index of specialization $(S)$ is the Gini coefficient, which measures the degree of concentration or inequality of the distribution of sector shares in an economy (Gini 1921) and is defined as follows: ${ }^{19}$

$$
S=\frac{2}{n^{2} \cdot \bar{s}} \sum_{j=1}^{n} j\left(s_{j}-\bar{s}\right),
$$

where $j$ denotes the sector, $n$ denotes the number of sectors, $s$ represents the share of each sector, and $\bar{s}$ refers to the average sector share. The index ranges from zero, where all sectors have an equal share of total manufacturing value added implying a perfectly diversified economy, to one, where only one sector produces all manufacturing value added, reflecting a strongly specialized economy. To check the robustness of our results, we also use two other indices of industrial specialization often used in the conventional literature. These indices are the Herfindahl-Hirschman index $(H R I)$, which sums up the square of each sector's share in the total manufacturing value added of a country, and the coefficient of variation of sector shares $(V S I)$, which is defined as the ratio of the standard deviation to the mean of sector shares in one country.

An important consideration in comparing specialization across countries is the level of aggregation at which the specialization measures are calculated. On the one

\footnotetext{
18 This holds even more for studies that use de jure (by law) measures of trade and finance, where one needs a considerable time span to see these policies to be realized.

19 The Gini coefficient is commonly used in the empirical literature to measure industrial specialization (Krugman 1991; Amiti 1999; Imbs 2004).
} 
hand, the lower the aggregation level, the more we risk contaminating our analysis of the openness-specialization nexus by differences in comparative advantage between small and large sectors in each country. To see why, consider a country in which the small sectors have a comparative advantage, compared to the large sectors. An increase in trade openness will then result in less specialization. On the other hand, the higher the aggregation level, the more we risk distorting our analysis of the openness-specialization nexus by picking up the general trend towards a more services oriented economic structure that is common among (most) countries in our sample. Trade openness will then correlate positively with specialization, but without any causality implied.

In this paper, we are interested in examining the industrial specialization patterns that result from changes in trade and financial openness. As a result, we focus on the manufacturing sector (where most international trade takes place), and we use industry-specific data from the EU KLEMS database, OECD structural analysis database (STAN) and the world input-output database (WIOD). We extract annual raw data on nominal value added for 20 NACE industries to compute the specialization indices. Table 5 in "Appendix A" lists all industries included in our index.

Our aim is to ensure that our index of choice, based on 20 NACE industries, minimizes the likelihood of both biases occurring. In order to verify this, we re-calculate the specialization indices using nominal value added and employment, aggregated to 11 NACE industries. In addition, we also take data at the ISIC 3-digit disaggregation (maximum 28 industries), for a subset of countries from the Nicita and Olarreaga (2007) database. The coverage of this database is fairly limited, and the quality of data varies hugely across countries. Therefore, we only use this data source for comparison purposes. Finally, we also calculate a specialization index at the highest aggregation level, with agriculture, services and manufacturing as the three sectors of the economy. Table 4 in "Appendix A" shows the Gini coefficient and its changes over time for each country in our sample. We find that Ireland, Cyprus and Latvia are the most specialized countries in our sample, whereas USA, UK and Austria are the least specialized ones. Ireland, USA and Slovenia experience the most significant increases in specialization, where their Gini coefficients rise by 32.1, 28.4 and 19.1\%. The Gini coefficients in Latvia, Estonia and Portugal decrease sharply by 17.7, 14.8 and $11.9 \%$. However, most countries in our sample become increasingly specialized since 1985.

Ideally, we aim to find that our preferred index is positively, significantly correlated with the lower aggregation indices, and not correlated with the highest aggregation index. Figure 4 in "Appendix A" shows scatterplots for the ISIC 3-digit Gini coefficient and the 3 -sector Gini, both compared to the 20 NACE Gini coefficient. The latter is indeed positively (0.477) and significantly (at the $1 \%$ level) correlated with the ISIC 3-digit Gini coefficient, whereas correlation with the 3-sector Gini coefficient is -0.077 , and not significantly different from zero. ${ }^{20}$

Therefore, we continue using the 20 NACE Gini coefficient as our main measure of specialization. For robustness purposes, we take into account the higher level sectoral composition changes by examining the openness-specialization nexus in two

${ }^{20}$ Correlation with the 11 NACE Gini coefficient is 0.7872 , and also significant at the $1 \%$ level. 
sub-samples. One includes countries that experience less changes in the manufacturing shares of GDP, whereas the other consists of countries that experience more changes. Finally, as our estimation strategy exploits the changes in specialization (i.e., we estimate in first differences), we do not expect that our results are driven by industry aggregations.

\subsection{Trade openness}

Our primary measure for trade openness is the ratio of imports plus exports divided by GDP $(T)$. This continuous measure is widely used in the empirical literature. For robustness purposes, we also use the share of imports to GDP (IMP) and the share of exports to GDP (EXP), as well as manufacturing trade as a percentage of GDP $(M A N T)$, a narrower measure of trade openness. To construct an instrument for trade openness in each country, we take the average of its neighboring countries' trade openness (Baltagi et al 2009).

Country-level data of trade volume, imports, exports, manufacturing trade, GDP have been taken from the World Bank World Development Indicators (WDI). Lastly, we also consider the role of intra-industry trade intensity (IIT) ${ }^{21}$ This measure allows for a more explicit test on the impact of trade integration, controlling for the nature of trade. We derive aggregate country-level IIT indicators from the OECD Structural Analysis database (STAN), which is computed using detailed trade data of two- and three-digit manufacturing industries.

\subsection{Financial openness}

We follow a similar approach with financial openness, where our primary measure $F$ is the ratio of total foreign assets to total foreign liabilities as a percentage of GDP. This stock-based measure is constructed following Lane and Milesi-Ferretti (2007). ${ }^{22}$ As in the case of trade openness, an external instrument for financial openness is also constructed for each country by taking the average of neighboring countries' financial openness. ${ }^{23}$

\footnotetext{
21 The Grubel-Lloyd index (Grubel and Lloyd 1975) of intra-industry trade is defined as: $\mathrm{IIT}_{i t}=1-\frac{\sum_{j}\left|\mathrm{EXPO}_{j i t}-\mathrm{IMPO}_{j i t}\right|}{\sum_{j}\left(\mathrm{EXPO}_{j i t}+\mathrm{IMPO}_{j i t}\right)}$, where $i$ denotes country, $j$ sector and $t$ year. It ranges from 0 , indicating pure inter-industry trade, to 1 , indicating pure intra-industry trade.

22 Unlike a flow-based measure, like gross capital inflow plus outflows divided by GDP, this stock-based measure takes into account the history of a country's financial integration and its changes over time. It is typically less prone to short-run changes in the political and economic climate and is thus a preferred measure for our purpose. See Edison et al. (2002) for the discussion of flow-based vs. stock-based measures.

23 We also compute the weighted average of its neighboring countries' trade and financial openness, weighted by the country size (i.e. the number of the population). We find the correlations between the unweighted and weighted measure are 0.845 and 0.976 for trade openness and for financial openness, respectively. The correlations remain unchanged, i.e. 0.847 and 0.978 if we use GDP as the weights. Therefore, following Baltagi et al (2009), we use the unweighted average.
} 
To address the issue of whether specific types of capital flows (and corresponding stocks) are more conducive to attaining the risk sharing benefits of financial integration, we construct three disaggregated measures of gross external assets and liabilities relative to GDP: equity (Equity), FDI (FDI) and debt (Debt). Data are retrieved from the Lane and Milesi-Ferretti (2007) database.

\subsection{Other variables}

To examine how financial development mediates the role of financial openness on specialization, we take liquid liabilities (currency plus demand and interest-bearing liabilities), relative to GDP as a proxy for financial development $(F D)$. This measure is the broadest available indicator of financial development, commonly described as "financial depth"(Levine 1997). We obtain it from the Beck et al. (1999) database.

The vector $Z$ includes country size (Size), measured by the population, as well as GDP per capita $(G D P p c)$ and its squared term $(G D P p c 2)$ to characterize the stage of economic development. Total population and GDP per capita (constant 2000 US dollars) are taken from the World Bank World Development Indicators (WDI). For the robustness analysis, we also include three additional control variables to capture country factor endowments, namely the size of agricultural production as a share of GDP (AGRI), total natural resource rents (sum of oil, natural gas, coal, minerals and forest rents) as a percentage of GDP (RES) and education attainment (HC) measured by the average years of schooling for the population aged 25 or over. Agricultural production and total natural resource rents are retrieved from the WDI and years of schooling is retrieved from Barro and Lee (2012) database. We interpolate these authors' data to obtain annual observations. Lastly, we include total factor productivity $(T F P)$ level $(2011=1)$ and the relative price of capital stock, where the level of the US in 2011 is set to 1 . Both measures are taken from Penn World Table version 9.0 (Feenstra et al. 2015).

Table 1 summarizes the definitions, sources and descriptive statistics of main variables as well as those used in robustness analysis, respectively. The presentation and discussion of the empirical findings is the subject of the next section.

\section{Empirical results}

This section presents the empirical results. We examine, first, how trade and financial openness relate to industrial specialization individually and, second, how they jointly relate to industrial specialization. ${ }^{24}$

\footnotetext{
${ }^{24}$ All of our results are based on the full sample. We perform some sub-sample analyses in "Appendix B". One potential concern is the unbalanced nature of the sample might bias our results. However, using a balanced panel would drastically reduce the number of countries and observations. We prefer therefore to use the full unbalanced sample. We have nevertheless checked whether our main results reported in Tables 2 and 3 are robust in a balanced panel. We find that the results are rather similar. In some cases, they even become more significant. These results are available upon request.
} 


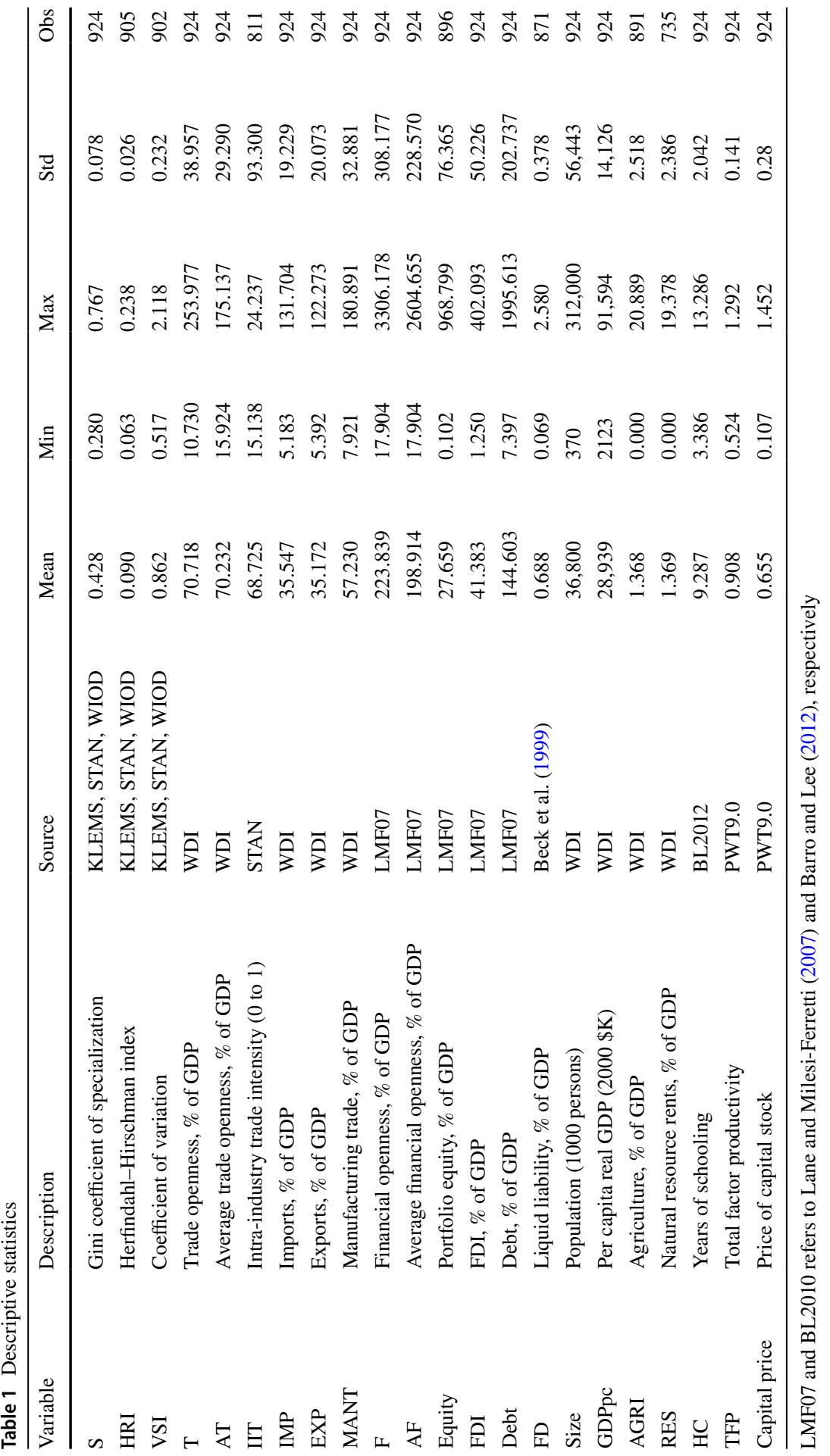




\subsection{Does openness matter for industrial specialization?}

We start by investigating the independent impact of trade and/or financial openness on industrial specialization. The results are reported in Table 2. Columns (I), (II) and (III) only consider the role of trade openness. Similarly, columns (IV), (V) and (VI) only include financial openness. In columns (VII), (VIII) and (IX), trade and financial openness are both included, but (not yet) interacted.

For every specification, we first report the OLS estimates, in columns (I), (IV) and (VII). However, the OLS estimator yields biased and inconsistent estimates of the causal effect of openness on specialization in the presence of endogenous regressors. Trade and financial openness are endogenous from a theoretical viewpoint due to reverse causality with specialization. Additionally, the DHW statistics often reject the null hypothesis that introducing instruments has no effect on the estimated coefficients and confirm that both trade and/or financial openness are indeed endogenous. We then proceed with the two-step GMM results using the lagged levels of trade and financial openness at $t-2, t-3$ and $t-4$ as instruments, in columns (II), (V) and (VIII). The validity of using lags from $t-2$ as instruments is guaranteed by not rejecting the absence of second-order serial correlation. Next, the Hansen $J$ test does not reject the over-identifying restrictions, confirming the validity of our instruments. Moreover, the Kleibergen-Paap rk test and the Anderson-Rubin test confirm that these specifications are properly identified and do not suffer from under- and weak-identification problems. Lastly, columns (III), (VI) and (IX) replicate (II), (V) and (VIII) with trade and/or financial openness instrumented by the average of neighboring countries' trade and/or financial openness. We obtain stronger results.

As columns (I)-(III) show, we find a statistically significant (at 1\%) positive relationship between trade openness and specialization. However, the Hansen $J$ tests indicate that the instruments used in column (II) and (III) are not valid. Turning to the role of financial openness in column (V)-(VI), we observe a statistically significant positive effect of financial openness on specialization, in line with the risk-sharing rationale put forward by Kalemli-Ozcan et al. (2003). By allowing access to foreign markets, financial integration can bring a wider range of financing sources and investment opportunities, permitting the decoupling of production and consumption via cross-country risk sharing mechanisms and making it less costly for countries to achieve greater specialization. In terms of magnitude, ceteris paribus, a one standard-deviation increase in the (log of) financial integration is associated with an increase in the (log of) Gini coefficient of 0.616 standard deviations. Moreover, the sign, magnitude and significance remain similar after introducing trade openness into the equation in column (VII)-(IX), suggesting that international finance has been an important force in driving increased specialization over time.

In line with past evidence (Imbs and Wacziarg 2003), we do not find a positive coefficient for country size. We find some evidence of a U-shaped relationship between GDP per capita and specialization. In the early stages of development, countries diversify and hold a more balanced structure of economic activities in order to reduce the negative impact of sector-specific shocks. At the later stages of development, countries begin to specialize to fully exploit comparative advantages. However, this result is not robust across all specifications. 


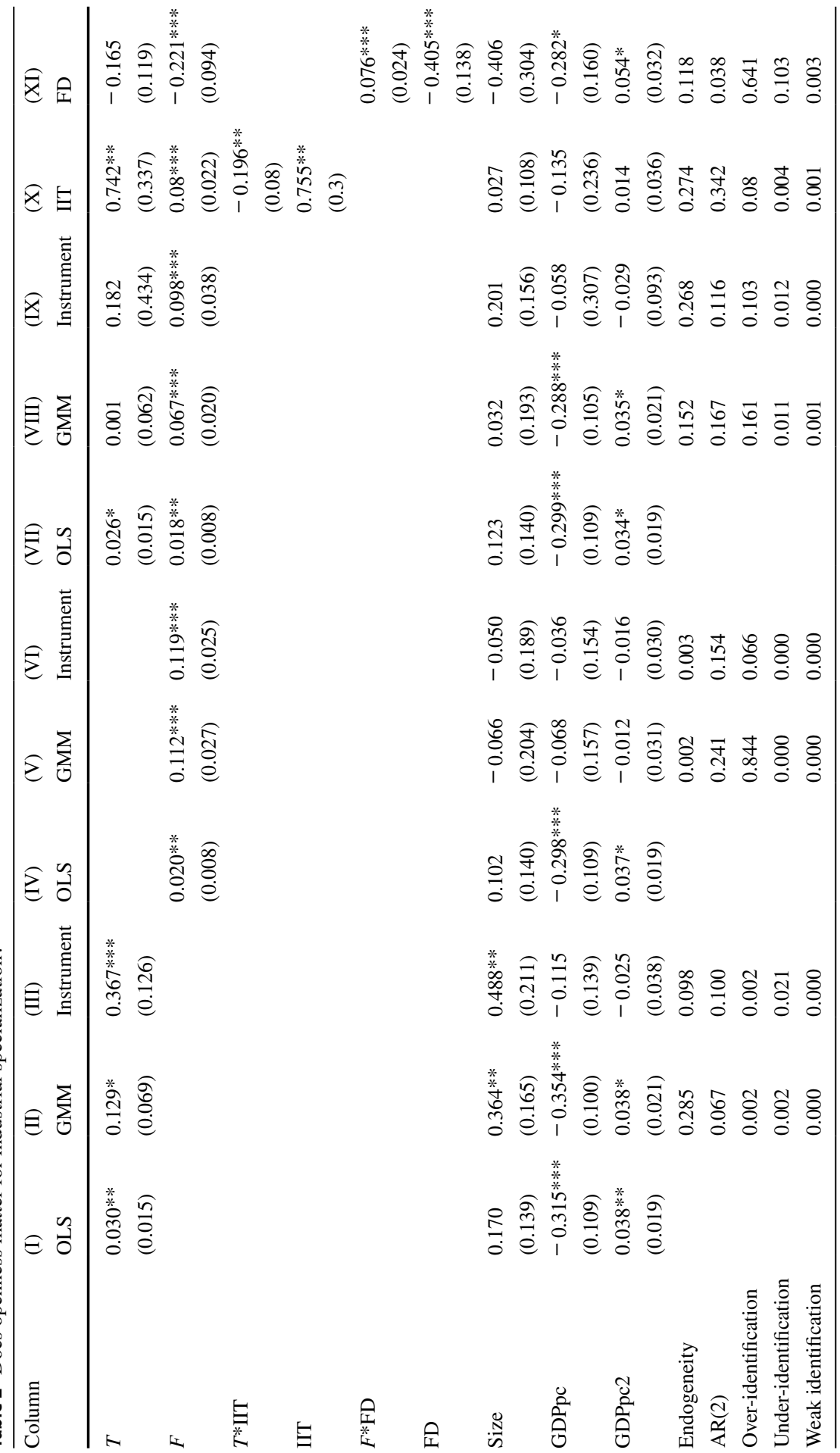




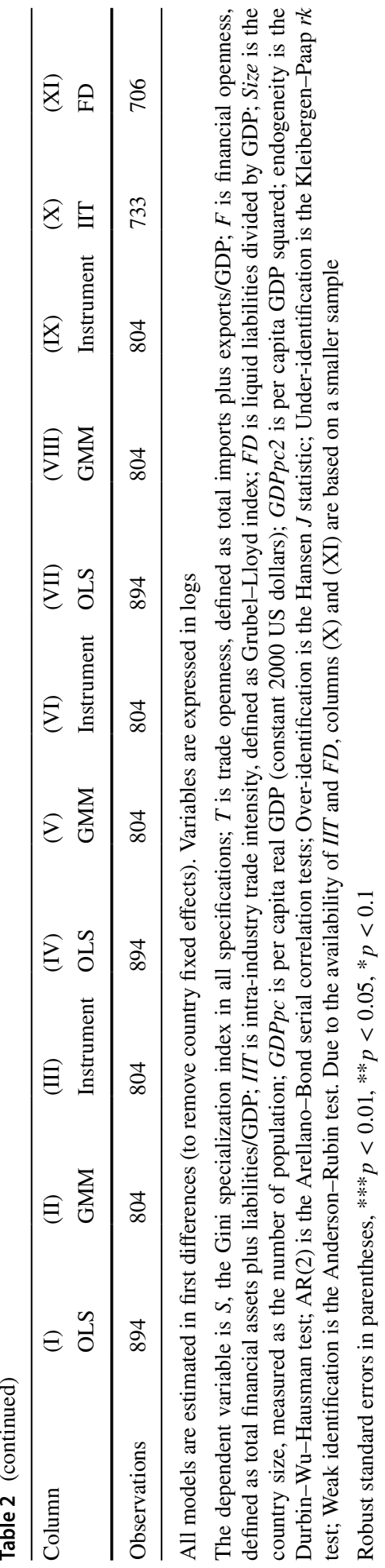


Having established that trade and financial openness have a significant relationship with specialization, we are interested in examining whether the strength of this relationship is determined by intra-industry trade (IIT) and financial development $(F D)$, respectively.

Classical trade theories postulate that further trade openness is likely to result in more specialization if trade is predominantly of the inter-industry type. On the contrary, if trade is of the intra-industry type, trade-induced specialization may be weaker, as trade leads countries to concentrate on the production of a limited number of products within the industry.

In column (X) in Table 2, an intra-industry trade intensity index IIT therefore interacts with trade openness. ${ }^{25}$ The index ranges from zero, indicating pure inter-industry trade, to one, indicating pure intra-industry trade. Both terms are individually and jointly significant at $1 \%$. The DHW statistic confirms that trade openness and its interaction term with IIT are endogenous, so we instrument lagged values at $t-2, t-3$ and $t-4$. The absence of second-order serial correlation and the inability to reject the overidentifying restrictions confirm the validity of our instruments. The Kleibergen-Paap $r k$ test and the Anderson-Rubin test suggest that this regression is well specified.

Figure 2a shows the marginal effect of trade openness on specialization, conditional on the intra-industry trade intensity. Consistent with column (VIII), trade openness has a positive relationship with specialization, independent of the level of intra-industry trade. In addition, we find that countries with high levels of intra-industry trade experience less specialization in response to further trade openness than countries with low levels of intra-industry trade. In line with our expectation, intra-industry trade seems to dilute the specialization effect of trade. Financial openness enters with a positive and statistically significant coefficient at the 5\% level. The magnitude is comparable to that found in column (V), but considerably larger than that found in column (VIII) in Table 2, confirming the important role of financial openness in driving specialization.

Next, we explore the role of financial development as a facilitator to the relationship between financial openness and specialization. A vast body of existing literature has strongly emphasized that benefits associated with financial openness only become significant at higher levels of financial development. ${ }^{26}$ Financial development facilitates financial openness as domestic financial intermediaries, who distribute international assets, offer a local channel by which investors can gain foreign exposure. The latter may also increase the desire for international diversification. Furthermore, a well-developed financial system is attractive to foreign investors. Thus, financial openness and financial development may be complements in shaping specialization.

\footnotetext{
25 Including both intra-industry trade and our traditional trade integration measure, as well as an interaction term, may raise concerns regarding multicollinearity. However, in light of our analysis of the conditional marginal effects in Fig. 2a, b, two aspects of columns (X) and (XI) are worth mentioning (Brambor et al. 2006). First, given the inclusion of interaction terms, we never intend to measure the average effect of a variable in the same way as we would in an additive model, as in column (IX). As a result, a change in coefficients as a result of including the interaction terms should not be interpreted as a sign of multicollinearity. Second, the main 'problem' with multicollinearity would be large standard errors, something that would be accurately captured by Fig. $2 \mathrm{a}, \mathrm{b}$ and would thereby not lead us to overstate the significance of our results.

26 See, for example, the studies of Masten et al. (2008) and Klein and Olivei (2008).
} 
(a) Intra-industry trade intensity as a mediator

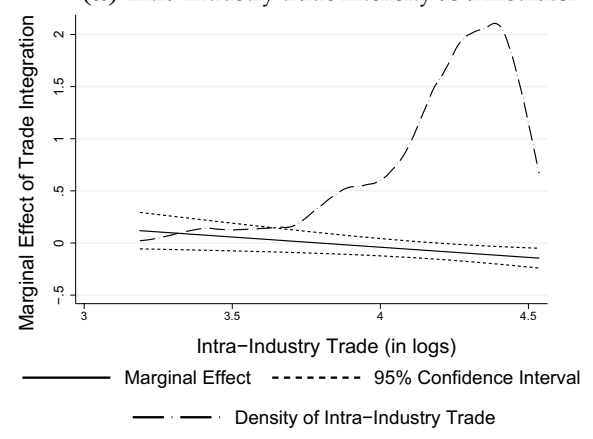

(b) Financial development as a mediator

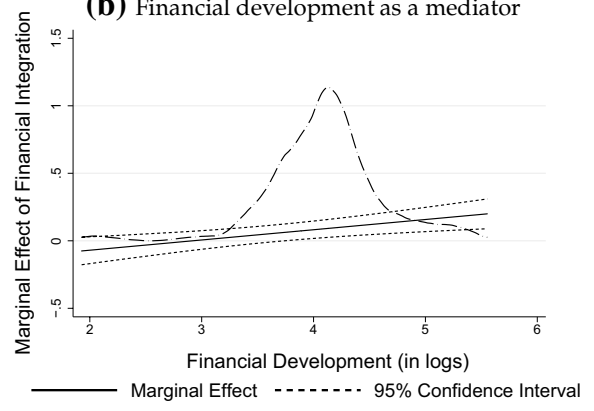

_ - Density of Financial Development

Fig. 2 The role of intra-industry trade intensity and financial development as mediators

In column $(\mathrm{XI})$, a financial development measure $(F D)$ therefore interacts with financial openness. We instrument financial openness using values at $t-2, t-3$ and $t-4$. The validity of the instruments is guaranteed by the absence of serial correlation and the inability to reject the over-identifying restrictions. The Kleibergen-Paap $r k$ test and the Anderson-Rubin test confirm the appropriateness of this specification.

Figure $2 \mathrm{~b}$ shows that the marginal effect of financial openness on specialization is positively associated with the degree of financial development, implying that the effect of financial openness in promoting specialization is larger in countries with more developed financial systems and smaller in those with less developed financial system.

To summarize, three key findings emerge from our analysis so far. First, financial and to a much less extent trade openness are important in explaining variations in industrial specialization across countries. Second, trade-induced specialization is stronger if trade is predominantly of the inter-industry type. Third, the effect of financial openness on specialization is particularly present when the level of financial development is high.

\subsection{Are openness to trade and financial openness complements?}

So far, we have neglected the possible connection between trade and financial openness in affecting specialization. We now proceed by examining the joint effect of trade and financial openness, as described in Eq. (2a).

The results are shown in columns (I) to (III) of Table 3. Column (I) reports the OLS estimates, which are likely to be biased and inconsistent since they neglect the endogeneity of trade openness, financial openness and their interaction term, as evidenced by the DHW statistic shown in column (III). In column (II), we report two-step GMM estimates where we use trade and financial openness as well as their interaction term using lagged values at $t-2, t-3, t-4$. Lastly, column (III) applies the average of neighboring countries' trade and financial openness as instruments. Again, the Arellano-Bond test and Hansen $J$ test guarantee the validity of our instruments. Finally, the Kleibergen-Paap $r k$ test and the Anderson-Rubin test show that 
Table 3 Are openness to trade and financial openness complements?

\begin{tabular}{|c|c|c|c|c|c|c|}
\hline Column & (I) & (II) & (III) & (IV) & $(\mathrm{V})$ & (VI) \\
\hline$T$ & $\begin{array}{l}-0.008 \\
(0.052)\end{array}$ & $\begin{array}{l}-0.225^{*} \\
(0.127)\end{array}$ & $\begin{array}{l}-1.248^{* * *} \\
(0.333)\end{array}$ & $\begin{array}{l}-0.525^{* *} \\
(0.205)\end{array}$ & $\begin{array}{l}-0.741^{* * *} \\
(0.226)\end{array}$ & $\begin{array}{l}-1.181 \text { *** } \\
(0.328)\end{array}$ \\
\hline$F$ & $\begin{array}{l}-0.014 \\
(0.046)\end{array}$ & $\begin{array}{l}-0.124 \\
(0.104)\end{array}$ & $\begin{array}{l}-0.63^{* * *} \\
(0.249)\end{array}$ & & & \\
\hline$T^{*} F$ & $\begin{array}{l}0.007 \\
(0.011)\end{array}$ & $\begin{array}{l}0.047 * * \\
(0.024)\end{array}$ & $\begin{array}{l}0.176^{* * * *} \\
(0.059)\end{array}$ & & & \\
\hline$T^{*}$ Equity & & & & $\begin{array}{l}0.062^{* *} \\
(0.024)\end{array}$ & & \\
\hline Equity & & & & $\begin{array}{l}-0.203 \\
(0.137)\end{array}$ & & \\
\hline$T^{*} \mathrm{FDI}$ & & & & & $\begin{array}{l}0.124 * * \\
(0.052)\end{array}$ & \\
\hline FDI & & & & & $\begin{array}{l}-0.423^{*} \\
(0.223)\end{array}$ & \\
\hline$T^{*}$ Debt & & & & & & $\begin{array}{l}0.205^{* * *} \\
(0.064)\end{array}$ \\
\hline Debt & & & & & & $\begin{array}{l}-0.748 * * * \\
(0.259)\end{array}$ \\
\hline Size & $\begin{array}{l}0.137 \\
(0.142)\end{array}$ & $\begin{array}{l}0.133 \\
(0.198)\end{array}$ & $\begin{array}{l}-0.081 \\
(0.359)\end{array}$ & $\begin{array}{l}-0.086 \\
(0.271)\end{array}$ & $\begin{array}{l}-0.253 \\
(0.313)\end{array}$ & $\begin{array}{l}0.214 \\
(0.372)\end{array}$ \\
\hline GDPpc & $\begin{array}{l}-0.294^{* * *} \\
(0.109)\end{array}$ & $\begin{array}{l}-0.205^{*} \\
(0.114)\end{array}$ & $\begin{array}{l}-0.26 \\
(0.183)\end{array}$ & $\begin{array}{l}-0.614 * * * \\
(0.226)\end{array}$ & $\begin{array}{l}-0.382 * * * \\
(0.191)\end{array}$ & $\begin{array}{l}-0.135 \\
(0.212)\end{array}$ \\
\hline GDPpc2 & $\begin{array}{l}0.033^{*} \\
(0.019)\end{array}$ & $\begin{array}{l}0.013 \\
(0.023)\end{array}$ & $\begin{array}{l}0.054 \\
(0.042)\end{array}$ & $\begin{array}{l}0.112^{* *} \\
(0.048)\end{array}$ & $\begin{array}{l}0.071 \\
(0.047)\end{array}$ & $\begin{array}{l}0.022 \\
(0.047)\end{array}$ \\
\hline $\mathrm{AR}(2)$ & & 0.144 & 0.34 & 0.284 & 0.225 & 0.484 \\
\hline Endogeneity & & 0.279 & 0.005 & 0.034 & 0.014 & 0.003 \\
\hline Over-identification & & 0.266 & 0.177 & 0.094 & 0.085 & 0.456 \\
\hline Under-identification & & 0.020 & 0.079 & 0.028 & 0.025 & 0.047 \\
\hline Weak identification & & 0.000 & 0.000 & 0.000 & 0.000 & 0.000 \\
\hline Observations & 894 & 804 & 804 & 788 & 834 & 804 \\
\hline
\end{tabular}

All models are estimated in first difference (to remove country fixed effects). Variables are expressed in logs

The dependent variable is $S$, the Gini specialization index in all specifications; $T$ is trade openness, defined as total imports plus exports/GDP; $F$ is financial openness, defined as total financial assets plus liabilities/GDP; Equity is the assets and liabilities of portfolio equity/GDP; FDI is the assets and liabilities of FDI/GDP; Debt is the assets and liabilities of debts/GDP; Size is the country size, measured as the number of population; GDPpc is per capita real GDP (constant 2000 US dollars); GDPpc2 is per capita GDP squared; Endogeneity is the Durbin-Wu-Hausman test; AR(2) are Arellano-Bond serial correlation tests; Over-identification is the Hansen $J$ statistic; Under-identification is the Kleibergen-Paap $r k$ test; Weak identification is the Anderson-Rubin test

Robust standard errors in parentheses, *** $p<0.01, * * p<0.05, * p<0.1$ 


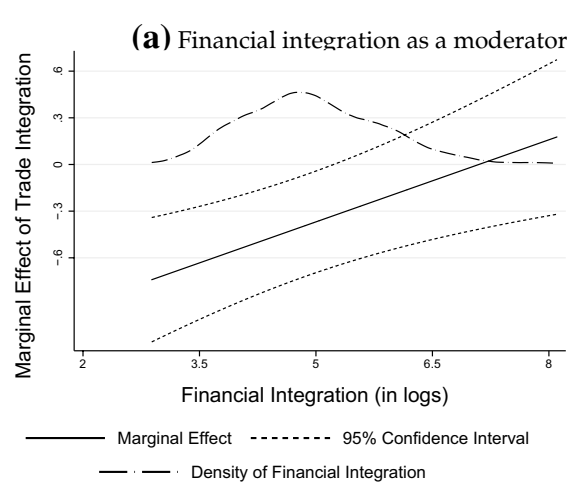

(b) Trade integration as a moderator

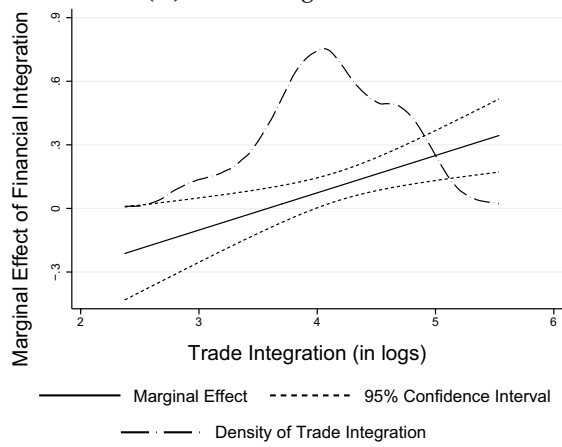

Fig. 3 The role of trade integration and financial integration as complements

Eq. (2a) is properly identified. Therefore, for the rest of our analyses we primarily rely on the estimates in column (III).

To see the role of each type of openness, we have to also consider the interaction effect, which enters with a positive sign, significant at the $1 \%$ level, suggesting a complementary relationship between trade and financial openness. In other words, the effect of trade openness is further enhanced by the degree of financial openness, and vice versa.

In order to further assess the strength of each type of openness, we calculate the marginal effect of one type of openness conditional on the other type, based on Eqs. (2b) and (2c). Figure 3a, b illustrates these conditional marginal effects and the corresponding 95\% confidence intervals (Brambor et al. 2006). ${ }^{27}$

Figure $3 \mathrm{a}$ demonstrates that trade openness always has a positive relationship with specialization, independent of the level of financial openness. To shed more light on the economic nature of the relationship between trade openness and specialization, we can now evaluate Eq. (2b) at the mean, minimum and maximum value of financial openness. The marginal effect of trade openness on specialization at the mean level of financial openness is -0.375 . When financial openness is at its lowest and we reach the bottom left corner of Fig. 3a, the marginal effect of trade openness is -0.741 . Finally, when financial integration peaks and we reach the top right corner of Fig. 3a, the effect

\footnotetext{
${ }^{27}$ The magnitude and significance of $\beta_{1}$ and $\beta_{2}$ in Eq. (2a) do not bear direct interpretation regarding the impact of trade and financial integration on specialization as the interaction term, i.e., $\beta_{3}$, needs to be taken into account. Since we are mainly interested in how trade and financial integration act as moderators of each other's relationship with specialization, we therefore compute the conditional marginal effect, following Brambor et al. (2006). This approach sheds more light on the threshold effects demonstrated in the following paragraphs. Ozer-Balli and Sorensen (2010) propose a different treatment and interpretation of linear regression models with interaction terms. They suggest that a model with a demeaned instead of a conventional interaction term is preferable as the former maintains the interpretation of the coefficients to main terms similar to a model without the interaction term, while keeping the coefficient on the interaction term (largely) unchanged. Following their approach, we re-estimate Eq. (2a), where in place of $T_{i t} x F_{i t}$, we use a demeaned interaction term $\left(T_{i t}-\bar{T}_{i t}\right) x\left(F_{i t}-\bar{F}_{i t}\right)$. We find that the coefficients of $T_{i t}$ and $F_{i t}$ bear positive signs, significant at $1 \%$ and $5 \%$, respectively, and the magnitudes are very close to those reported in column (VIII) in Table 2. Moreover, the coefficient on the demeaned interaction team is slightly higher than that of the conventional interaction term $T_{i t}$ and $F_{i t}$ reported in column (II) in Table 3.
} 
of trade integration is $0.177 .{ }^{28}$ Summing up, trade openness results in more specialization as countries become more financially integrated. Once risk sharing opportunities - caused by the higher level of financial integration - are sufficient, trade openness appears to induce specialization. This result is also in line with the argument that financial openness facilitates the reallocation of capital to sectors that have a comparative advantage, thus increasing the opportunities for trade (Feeney 1994a, b).

Figure $3 \mathrm{~b}$ demonstrates that the relationship between financial openness and specialization strongly depends on the level of trade openness. We find evidence of a threshold effect, since the positive effect of financial openness on specialization only occurs when countries are sufficiently open to international trade. The marginal effect of financial integration becomes positive when the log of trade openness is equal to 3.58 , corresponding to a trade openness ratio of approximately $35 \%$ of GDP. At the mean level of trade openness, the impact of financial integration on specialization is 0.093 . When evaluated at the minimum level, the impact takes the value of -0.212 , while it becomes 0.343 when the level of trade openness reaches its maximum. ${ }^{29}$ This finding provides evidence that growing trade flows create extra demands for international insurances and enlarge the scope for financial openness to have a bigger impact on specialization.

Our results also relate to a strand of recent research documenting that the level of trade openness matters for the effects of financial openness. ${ }^{30}$ For example, more open economies are found to be less vulnerable to financial crises (Calvo et al. 2004; Edwards 2004a; Cavallo and Frankel 2008). Countries that are more open to trade suffer smaller growth declines than those with a lower degree of trade openness (Guidotti et al. 2004; Edwards 2004b). Such findings are consistent with the notion that trade integration precedes financial integration. In other words, (developing) countries should liberalize trade before they liberalize capital flows. Our results also lend support to this notion as finance-induced specialization can only be realized when a threshold level of trade openness is achieved.

A widespread view from the literature is that the extent of risk sharing achieved via financial integration is not only dependent on the overall size of capital flows, but also on their composition, i.e., the relative shares of portfolio equity, FDI and external debt. Portfolio equity and FDI flows are perceived to be more conductive to risk sharing (Kose et al. 2009b), whereas debt flows are more prone to sudden stops, triggering economic crises. Thus, it would be desirable for (emerging) countries to reduce their reliance on debt finance and increase the importance of equity investments and FDI (Rogoff 1999).

To investigate whether the specific types of capital flows (or the corresponding stocks) have different effects on specialization, we focus on three narrower measures of financial openness, corresponding to the stocks of total portfolio equity (Equity), FDI $(F D I)$ and debt (Debt) relative to GDP, respectively. We re-estimate Eq. (2a) but replace $F$ with Equity, FDI, and Debt. We want to uncover whether portfolio equity

\footnotetext{
${ }^{28}$ The calculation is as follows: $-1.248+0.176 \times 4.96=-0.375,-1.248+0.176 \times 2.88=-0.741$, $-1.248+0.176 \times 8.1=0.177$, all numbers are expressed as elasticities.

${ }^{29}$ The calculation is as follows: $-0.63+0.176 \times 4.11=0.093,-0.63+0.176 \times 2.37=-0.212$, $-0.63+0.176 \times 5.53=0.343$.

${ }^{30}$ For a comprehensive survey, see Kose et al. (2009b).
} 
and/or FDI flows are more conducive to risk sharing, therefore exerting a greater positive impact on specialization.

Columns (IV), (V) and (VI) in Table 3 report the estimates. ${ }^{31}$ The DHW statistics confirm that trade and financial openness (different types of stocks), together with their interaction term, are indeed endogenous variables. The diagnostic tests again confirm the validity of our instruments and the proper identification of the results.

With the results in columns (IV) to (VI), we also compute the marginal effects of trade openness on specialization at the mean level of portfolio equity, FDI and debt, respectively. In contrast to Kose et al. (2009b) and Rogoff (1999), we find that the marginal effect is largest for debt $(0.176)$, followed by FDI $(-0.03)$ and portfolio equity ( -0.078$)$, respectively.

We conduct a series of robustness checks based on Eq. (2a) and demonstrate that our results are insensitive to alternative measures, samples and specifications. In "Appendix B", we present the details of the robustness checks.

Summing up, we find that trade and financial openness are complementary in their effects on specialization. We find a threshold effect for trade openness as a moderator for the effect of financial openness on specialization.

\section{Conclusion}

This paper investigates the economic integration-industrial specialization nexus and empirically establishes the direct linkages between trade, financial openness and industrial specialization for a panel of 31 countries over the period 1970-2005.

We contribute to the existing literature by answering two important questions. First, we document the relationship between economic integration and specialization via two separate channels, trade and financial openness. We find a statistically significant and positive relationship between trade openness and specialization, suggesting that further openness to foreign trade induces a more specialized industrial structure, and a statistically significant positive effect of financial openness on specialization, in line with the risk-sharing rationale put forward by Kalemli-Ozcan et al. (2003), and subsequently confirmed by Basile and Girardi (2010) and Imbs (2004). In terms of magnitude, the impact of trade openness appears to be larger than that of financial openness. In addition, our results reveal that trade openness has a stronger relationship with specialization in countries with low levels of intra-industry trade. Financial openness has a stronger relationship with specialization in countries with more developed financial systems, although this complementary effect does not appear to be very strong.

Second, we show that the role of trade (financial) openness is further enhanced by the degree of financial (trade) openness. Our finding indicates that trade and financial openness complement each other in shaping industrial specialization across countries. More importantly, we find that financial openness co-exists with high degrees of specialization only if countries are sufficiently open to trade. These

\footnotetext{
31 The corresponding OLS results are with the correct sign, albeit less significant due to the endogeneity problems. Similar to column (III), we use the average of neighboring countries' trade and financial openness as instruments as our preferred specification.
} 
findings extend Imbs (2004) by offering additional insights in understanding trade and financial openness as joint determinants of specialization across countries. Moreover, we find some evidence that portfolio equity, FDI and debts are all effective instruments in complementing trade openness. Overall, our results are robust to a wide range of alternative measures and estimation strategies.

A main implication of our results is the importance of simultaneously deepening trade and financial integration. Countries that exploit integration along both lines can expect to benefit the most from integration, while insuring themselves against idiosyncratic shocks. However, both effects depend crucially on the degree to which trade is intra-industry and the level of development of the domestic financial system. On the one hand, countries with more intra-industry trade and a low level of financial development may not reap great benefits from specialization. On the other hand, countries with large inter-industry trade and a relatively high level of financial development stand to gain the most from increased trade and financial integration, as the former will allow them to reap the fruits of comparative advantage, whereas the latter may improve risk sharing. Finally, our analysis underlines the fact that in the presence of asymmetric shocks, there is still a need for better risk-sharing mechanisms, in particular in the presence of common policy objectives, such as is the case, for example, in the Eurozone.

A clear limitation of our study is the use of country-level data. While a country-level study offers us valuable insights into the relationship between openness and specialisation, in future research, this issue could be examined using industry-level and firm-level data.

A growing strand of theoretical and empirical studies on the effect of trade openness featuring firm heterogeneity has shown promising results (Melitz 2003; Pavcnik 2002; Trefler 2004; Bernard et al. 2006). This literature documents that the reduction of trade barriers has caused major restructuring across industries and countries. A substantial part of the effect of international trade is channeled through the reallocation of resources with the industry, which in turn shapes the industry aggregates. Bos and Zhang (2013) uncover that the true divers of the trade-specialization nexus are productive firms, who benefit from the increase in trade openness and can appropriate resources from less productive firms, thus causing the industry in which they operate to expand, at the expense of other industries, in which there is no room to make such moves. This finding suggests that firm-level dynamics are important in understanding industry-level outcomes and adds to our knowledge on trade-specialization nexus, beyond the lesson taught by country-level analysis.

Moreover, a number of studies have documented the role of trade, as a conduit of knowledge dissemination on output/productivity growth and innovation of the recipient country (Coe and Helpman 1995; Keller 2002a, b; Papageorgiou et al. 2007). In particular, Drivas et al. (2016) confirm that the trade of goods (i.e., embodied knowledge) constitutes an important channel for knowledge diffusion and local production of innovation in the USA. They further demonstrate that disembodied knowledge through citation and traded patent flows has a stronger positive effect on a state's innovation activity. We expect that as trade openness deepens, structural changes may be further enhanced by the effects on knowledge accumulation and spillovers.

In all, the use of disagregated data opens up new avenues for identifying the precise mechanisms at work, for better tackling the heterogeneity issue, and applying novel techniques to deal with the endogeneity problems, therefore improve our understanding of the openness-specialization nexus. 
Open Access This article is distributed under the terms of the Creative Commons Attribution 4.0 International License (http://creativecommons.org/licenses/by/4.0/), which permits unrestricted use, distribution, and reproduction in any medium, provided you give appropriate credit to the original author(s) and the source, provide a link to the Creative Commons license, and indicate if changes were made.

\section{Appendix A Tables and figures}

See Tables 4, 5 and Fig. 4.

Table 4 Specialization patterns across countries

\begin{tabular}{|c|c|c|c|}
\hline Country & $\begin{array}{l}\text { Specialization (aver- } \\
\text { age) }\end{array}$ & $\Delta$ Specialization & $\begin{array}{l}\Delta \text { Specializa- } \\
\text { tion }(>1985)\end{array}$ \\
\hline Australia (1970-2004) & 0.423 & 11.371 & 9.112 \\
\hline Austria (1970-2009) & 0.355 & -1.254 & 14.482 \\
\hline Belgium (1970-2011) & 0.445 & 9.551 & 10.112 \\
\hline Canada (1979-2006) & 0.366 & 1.02 & -1.283 \\
\hline Cyprus (1995-2011) & 0.593 & 12.426 & 12.426 \\
\hline Czech Republic (1995-2011) & 0.41 & 6.217 & 6.217 \\
\hline Denmark (1970-2011) & 0.482 & 8.74 & 15.79 \\
\hline Estonia (1995-2009) & 0.468 & -14.753 & -14.753 \\
\hline Finland (1970-2009) & 0.423 & 4.383 & 10.084 \\
\hline France (1970-2008) & 0.373 & -7.055 & 6.767 \\
\hline Germany (1970-2010) & 0.411 & 5.873 & 7.497 \\
\hline Greece (1970-2011) & 0.51 & 15.199 & 15.281 \\
\hline Hungary (1995-2010) & 0.404 & 5.345 & 5.345 \\
\hline Ireland (1970-2011) & 0.604 & 32.087 & 32.303 \\
\hline Italy (1970-2009) & 0.371 & 9.641 & 16.112 \\
\hline Japan (1973-2008) & 0.37 & 8.354 & 19.918 \\
\hline Korea (1970-2010) & 0.411 & -6.285 & 25.732 \\
\hline Latvia (1995-2011) & 0.591 & -17.716 & -17.716 \\
\hline Lithuania (1995-2011) & 0.548 & 9.873 & 9.873 \\
\hline Malta (1995-2004) & 0.549 & 9.112 & 9.112 \\
\hline Netherlands (1970-2009) & 0.469 & 18.12 & 8.796 \\
\hline Norway (1980-2007) & 0.445 & 16.341 & 11.789 \\
\hline Poland (1995-2007) & 0.371 & 6.152 & 6.152 \\
\hline Portugal (1970-2006) & 0.442 & -11.977 & -9.267 \\
\hline Slovakia (1995-2011) & 0.372 & 12.084 & 12.084 \\
\hline Slovenia (1995-2009) & 0.396 & 19.148 & 19.148 \\
\hline Spain (1970-2009) & 0.395 & -10.279 & 9.011 \\
\hline Sweden (1970-2009) & 0.4 & 2.332 & -1.008 \\
\hline UK (1970-2007) & 0.357 & 8.444 & 15.415 \\
\hline USA (1970-2011) & 0.316 & 28.396 & 38.952 \\
\hline
\end{tabular}

The time span for each country is in parentheses. Specialization is the Gini coefficient (value added) in 2005 
Table 5 Industries and NACE Codes

\begin{tabular}{ll}
\hline Industry & NACE Code \\
\hline Food, beverages and tobacco products & $15-16$ \\
Textiles, wearing apparel & $17-18$ \\
Leather products and footwear & 19 \\
Wood products and cork & 20 \\
Pulp, paper products & 21 \\
Publishing and printing & 22 \\
Coke, refined petroleum and nuclear fuel & 23 \\
Pharmaceuticals & 24 \\
Rubber and plastics products & 25 \\
Other non-metallic mineral products & 26 \\
Basic metals & 27 \\
Fabricated metal products & 28 \\
Machinery, NEC & 29 \\
Office machinery & 30 \\
Other electrical machinery & 31 \\
Electronic valves and tubes & 32 \\
Scientific instruments & 33 \\
Motor vehicles, trailers and semi-trailers & 34 \\
Building repairing aircraft and spacecraft & 35 \\
Manufacturing nec, recycling & $36-37$
\end{tabular}

(a) Comparison with lower aggregation
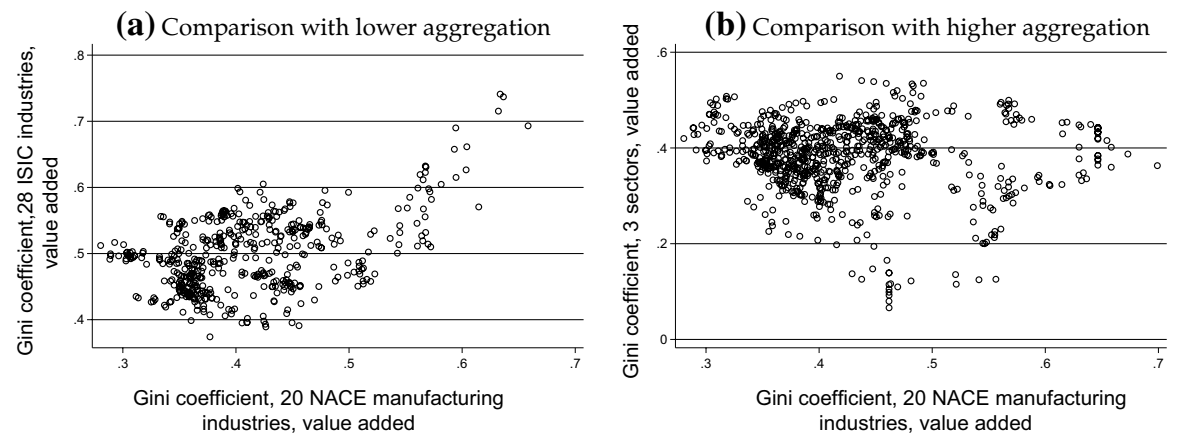

Fig. 4 Specialization at different aggregation levels

\section{Appendix B Robustness analyses}

We perform a number of robustness checks based on Eq. (2a) and demonstrate that our results are insensitive to alternative measures, samples and specifications in Table 6.

We first consider alternative measures of trade openness. Columns (I), (II) and (III) in Table 6 employ the imports share to GDP (IMP), exports share to GDP $(E X P)$ and manufacturing trade openness (MANT), respectively. Results are very 
similar to those reported in column (II) in Table 3. Overall, our results do not seem to be driven by the choice of a particular trade openness measure.

Next, we check whether the estimation results are driven by outliers. One or more very open countries could potentially drive the results. We drop Ireland, where the financial openness is the highest in our sample, re-run the estimation and find quantitatively similar results in column (IV) in Table 6.

Furthermore, we adopt two other measures of industrial specialization, namely the Herfindahl-Hirschman index (HRI) and the coefficient of variation (VSI), calculated using value added data on 20 NACE industries. Results are reported in columns (V) and (VI) in Table 6. We find no changes to our main findings.

One possible source of bias in our estimates is that changes in industrial specialization may capture the declining share of manufacturing in general. Based on the distribution of in-sample changes in manufacturing shares of total GDP, we therefore construct two sub samples, one excluding countries in the highest quantile, and the other one excluding the lowest quantile. We find that the results, reported in columns (VII) and (VIII), are qualitatively similar across the two sub samples, meaning that the changes in specialization cannot be attributed to the contraction of manufacturing activity as a whole.

Another potential bias may arise from the equal treatment of large and small countries. The dynamic relationship between openness and specialization may differ across these two groups of countries. To further investigate the effect of country size, we employ the same methodology as previously, following Imbs and Wacziarg (2003), where we construct two sub-samples, one excluding countries in the highest quantile of the distribution of country size, measured as total population, the other one excluding countries in the lowest quantile. The results are shown in columns (IX) and (X) in Table 6. We find that the estimated openness-specialization nexus is very similar using these two samples.

In addition, we examine whether the openness-specialization relationship has changed over time. To do so, we split the sample at 1985, run the same specification for both sub samples and report results in columns (XI) and (XII) in Table 6. We find no evidence that the estimated relationships are substantially different over time, albeit the significance decreases somewhat in the post 1985 sample. We further examine the robustness of the results by excluding the latest financial crisis period in column (XIII). Again we find no changes to our main results. We conclude that the latest financial crisis does not drive our results.

Furthermore, we check whether our results are driven by the time effects in two ways. We include a linear time trend in column (XIV) and a series of time dummies (per every 5-year period) in column (XV), respectively. The results are very similar. Therefore, we find no support of possible time effects that could potentially drive our results.

We also control for the effects of country factor endowments on specialization by including the agricultural production, natural resource rents and education attainment in column (XVI). None of these variables appear to be significantly correlated with specialization in our sample. The main results are again very similar and thus not affected by country factor endowments. 


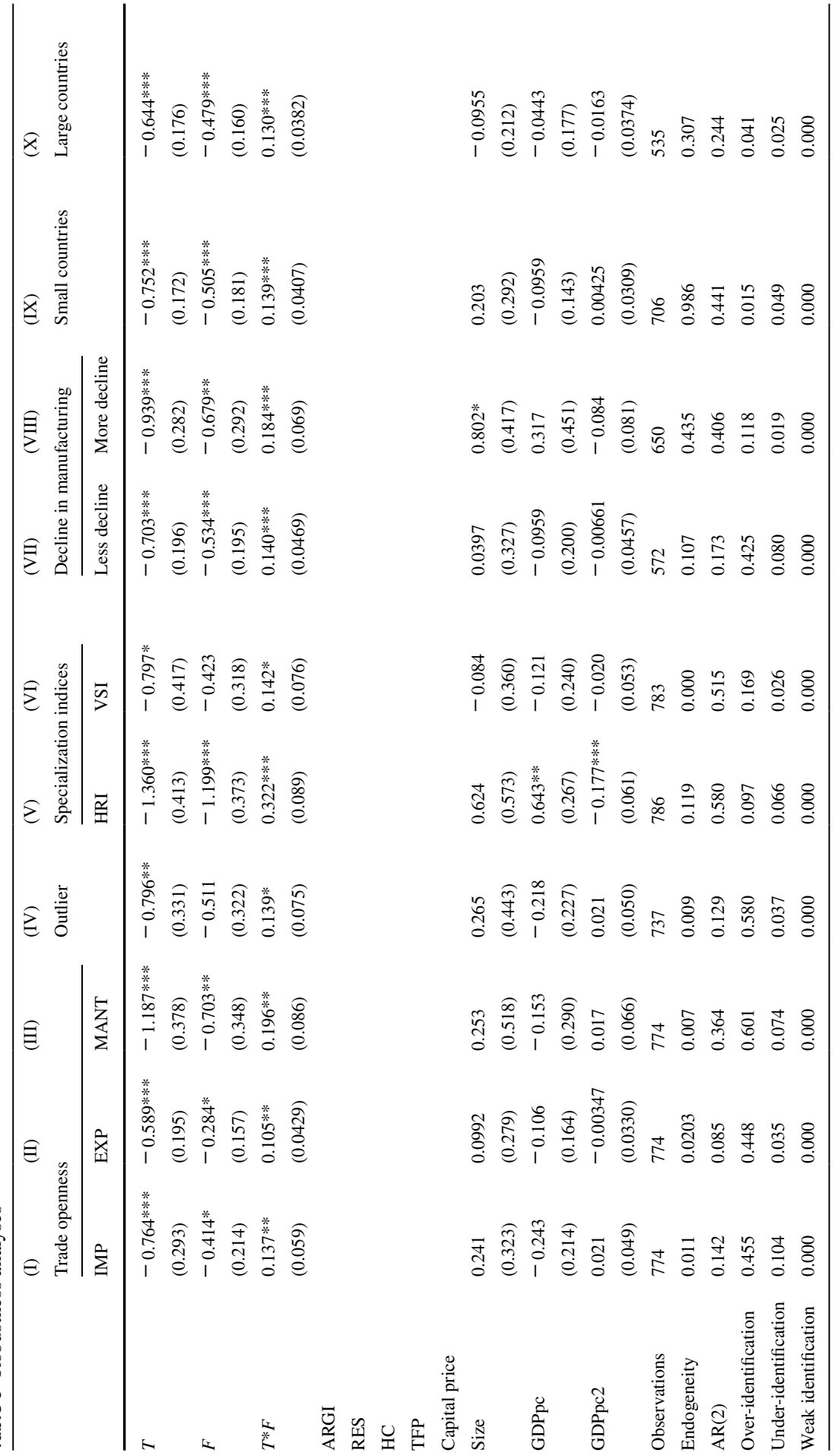




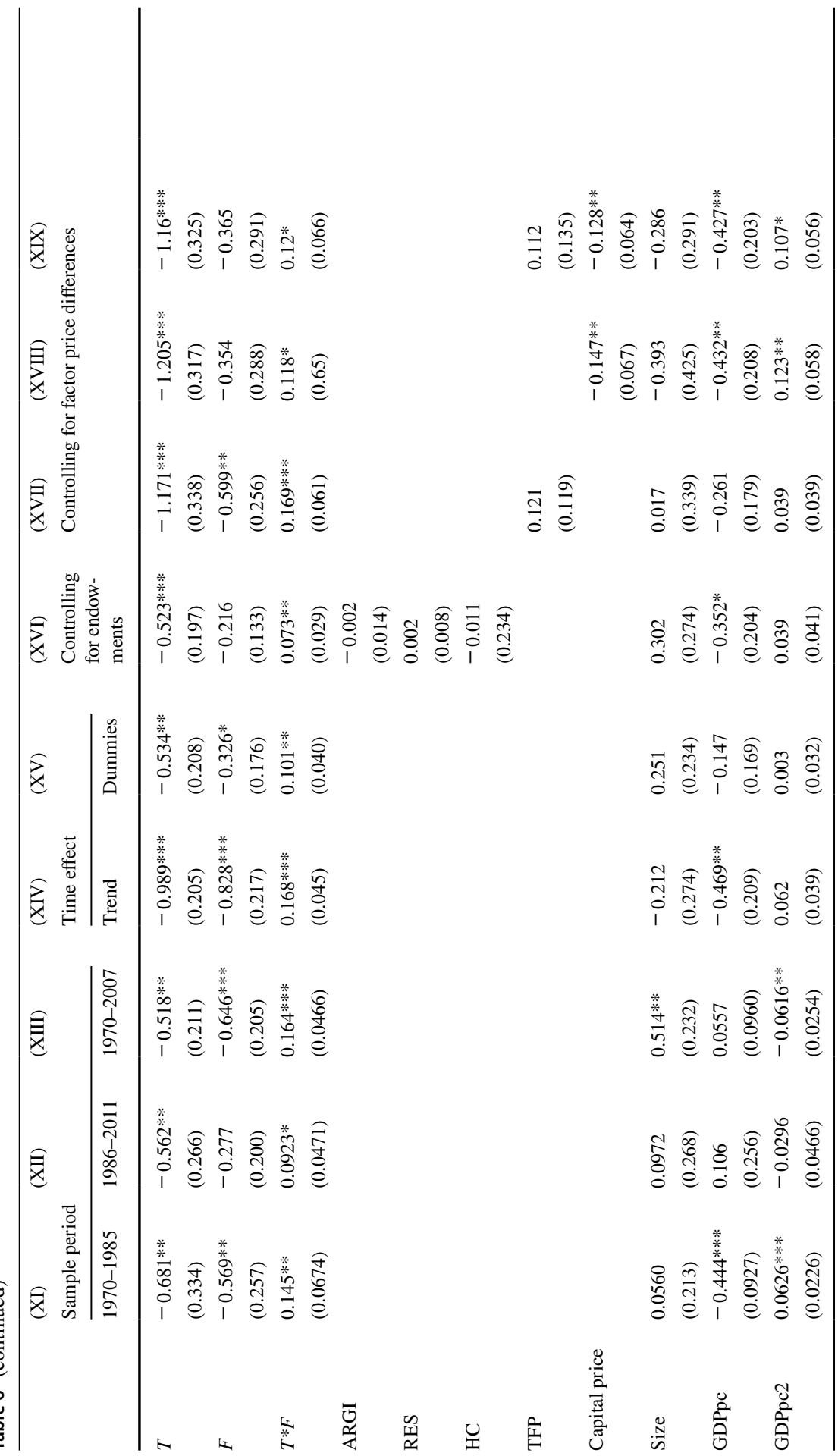




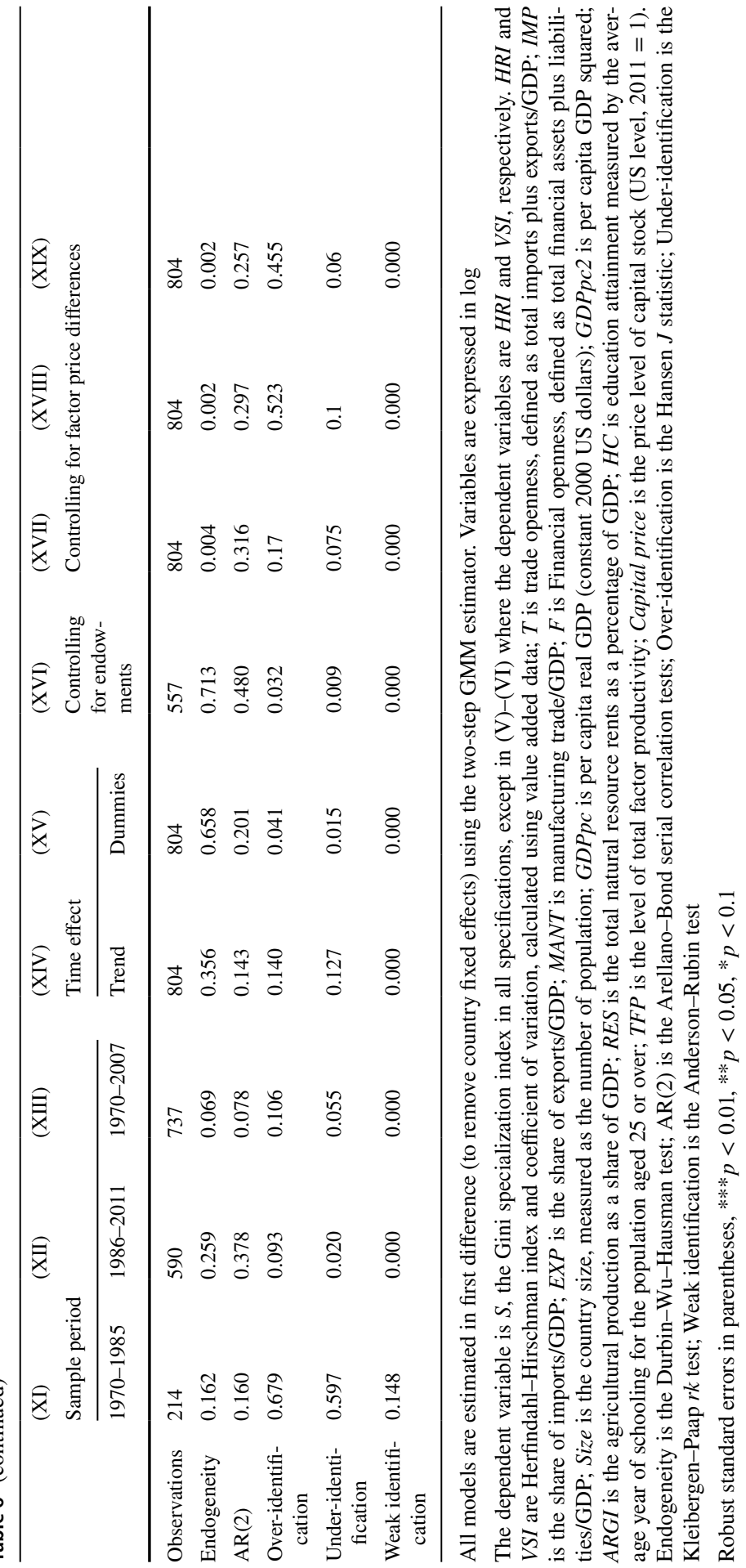


Lastly, we control for international factor price differences which may drive industrial specialization (Trefler 1993). ${ }^{32}$ Column (XVII) includes the level of total factor productivity, which has no influence to our main results. This result shows that productivity differences do not appear to be a driver of specializaiton in our sample. Column (XVIII) reports the results including the price of capital stock and wage rate (proxied by GDP per capita). Both capital price and wage rate carry significant negative signs, meaning that specialization is a reflection of international factor price differences. Albeit the magnitude and significance decrease somewhat, the interaction effect of trade and financial openness remain significant, suggesting that trade and financial openness matter and exacerbate price differences and comparative advantages of countries in international market.

In summary, we conclude that our findings are robust to a wide range of alternative measurement strategies.

\section{References}

Acemoglu D, Zilibotti F (1997) Was prometheus unbound by chance? Risk, diversification, and growth. J Polit Econ 105:709-51

Aizenman J, Noy I (2009) Endogenous financial and trade openness. Rev Dev Econ 13:175-189

Amiti M (1999) Specialization patterns in Europe. Rev World Econ (Weltwirtschaftliches Archiv) 135:573-593. https://doi.org/10.1007/BF02707385

Antràs P, Caballero RJ (2009) Trade and capital flows: a financial frictions perspective. J Polit Econ 117:701-744. https://doi.org/10.1086/605583

Artis MJ, Hoffmann M (2007) Declining home bias and the increase in international risk sharing: lessons from European integration. CEPR discussion papers 6617, pp 1-29. http://ideas.repec.org/p/ cpr/ceprdp/6617.html. Accessed 20 Sep 2010

Bai Y, Zhang J (2006) Financial integration and international risk sharing. Society for economic dynamics 2006 meeting paper 371, pp 1-31. http://ideas.repec.org/p/red/sed006/371.html. Accessed 30 Nov 2009

Baltagi BH, Demetriades PO, Law SH (2009) Financial development and openness: evidence from panel data. J Dev Econ 89:285-296

Barro RJ, Lee JW (2012) A new data set of educational attainment in the world, 1950-2010. J Dev Econ. https://doi.org/10.1016/j.jdeveco.2012.10.001(forthcoming)

Basile R, Girardi A (2010) Specialization and risk sharing in European regions. J Econ Geogr 10:645659. https://doi.org/10.1093/jeg/lbp047

Baum CF, Schaffer ME, Stillman S (2003) Instrumental variables and GMM: estimation and testing. Stata J 3:1-31

Beck T, Demirgüc-Kunt A, Levine R (1999) A new database on financial development and structure. World Bank Econ Rev 4:597-605

Beck T, Demirgüc-Kunt A, Laeven L, Maksimovic V (2006) The determinants of financing obstacles. J Int Money Finance 25:932-952

Beine M, Coulombe S (2007) Economic integration and the diversification of regional exports: evidence from the Canadian-U.S. free trade agreement. J Econ Geogr 7:93-111. https://doi.org/10.1093/jeg/ $1 \mathrm{~b} 1022$

Bellemare M, Masaki T, Pepinsky TB (2017) Lagged explanatory variables and the estimation of causal effect. J Polit 79:949-963

Bernard AB, Jensen JB, Schott PK (2006) Survival of the best fit: exposure to low-wage countries and the (uneven) growth of U.S. manufacturing plants. J Int Econ 68:219-237

Bos J, Zhang L (2013) Room to move: why some industries drive the trade-specialization nexus and others do not. Technical Report. Meteor Research Memorandum RM/13/03

32 We thank an anonymous referee for this suggestion. 
Brambor T, Clark W, Gold M (2006) Understanding interaction models: improving empirical analyses. Polit Anal 14:64-81

Brülhart M (2001) Growing alike or growing apart? Industrial specialization of EU countries. In: Wyplosz C (ed) The impact of EMU on Europe and the developing countries. Oxford University Press, Oxford, pp 1-35

Calderón C, Chong A, Stein E (2007) Trade intensity and business cycle synchronization: Are developing countries any different? J Int Econ 71:2-21. https://doi.org/10.1016/j.jinteco.2006.06.001

Calvo GA, Izquierdo A, Mejia LF (2004) On the empirics of sudden stops: the relevance of balance-sheet effects. NBER working paper 10520, pp 1-30. http://www.nber.org/papers/w10520. Accessed 25 June 2009

Cavallo EA, Frankel JA (2008) Does openness to trade make countries more vulnerable to sudden stops, or less? Using gravity to establish causality. J Int Money Finance 27:1430-1452

Chambet A, Gibson R (2008) Financial integration, economic instability and trade structure in emerging markets. J Int Money Finance 27:654-675

Chow HK, Kriz PN, Mariano RS, Tan AHH (2005) Trade, investment and financial integration. Report for the ASEAN+3 Secretariat, pp 1-155. http://www.aseansec.org/17898.pdf. Accessed 25 Jan 2011

Coe DT, Helpman E (1995) International R\&D spillovers. Eur Econ Rev 39:859-887

Crabbé K, Beine M, Vandenbussche H (2007) Trade, institutions and export specialization in Central Europe. Katholieke Universiteit Leuven working paper 264657, pp 1-31. http://ideas.repec.org/p/ ner/leuven/urnhdl123456789-264657.html. Accessed 20 March 2009

Dornbusch R, Fischer S, Samuelson PA (1977) Comparative advantage, trade, and payments in a Ricardian model with a continuum of goods. Am Econ Rev 67:823-839

Drivas K, Economidou C, Karkalakos S, Tsionas EG (2016) Mobility of knowledge and local innovation activity. Eur Econ Rev 85:39-61

Eckel C (2008) Globalization and specialization. J Int Econ 75(1):219-228

Edison HJ, Levine R, Ricci L, Slok T (2002) International financial integration and economic growth. J Int Money Finance 21:749-776

Edwards S (2004a) Financial openness, sudden stops, and current-account reversals. Am Econ Rev 94:59-64

Edwards S (2004b) Thirty years of current account imbalances, current account reversals and sudden stops. IMF staff papers 51, pp 1-49. http://www.jstor.org/pss/30035884

Feeney J (1994a) Goods and asset market interdependence in a risky world. Int Econ Rev 35:551-63

Feeney J (1994b) International market interdependence and learning-by-doing in a risky world. Rev World Econ (Weltwirtschaftliches Archiv) 130:101-117

Feenstra RC, Inklaar R, Timmer MP (2015) The next generation of the penn world table. Am Econ Rev 105:3150-3182

Frankel JA, Rose AK (1998) The endogeneity of the optimum currency area criteria. Econ J 108:1009-1025

García-Herrero A, Ruiz JM (2008) Do trade and financial linkages foster business cycle synchronization in a small economy? Banco de España working papers 0810, pp 1-39. http://ideas.repec.org/p/bde/ wpaper/0810.html. Accessed 15 April 2011

Gini C (1921) Measurement of inequality of incomes. Econ J 31:124-126

Greenwood J, Jovanovic B (1990) Financial development, growth, and the distribution of income. J Polit Econ 98:1076-1107

Grubel HG, Lloyd P (1975) Intra-Industry trade: the theory and measurement of international trade in differentiated products. MacMillan, London

Guidotti PE, Sturzenegger F, Villar A (2004) On the consequences of sudden stops. Economía 4:171-274

Harrison AE, McMillan MS (2003) Does direct foreign investment affect domestic credit constraints? J Int Econ 61:73-100

Imbs J (2004) Trade, finance, specialization, and synchronization. Rev Econ Stat 86:723-734

Imbs J (2006) The real effects of financial integration. J Int Econ 68:296-324

Imbs J, Wacziarg R (2003) Stages of diversification. Am Econ Rev 93:63-86

Inklaar R, Jong-A-Pin R, de Haan J (2008) Trade and business cycle synchronization in OECD countriesa re-examination. Eur Econ Rev 52:646-666

Kalemli-Ozcan S, Nikolsko-Rzhevskyy A (2010) Does trade cause capital to flow? Evidence from historical rainfalls. NBER working papers 16034, pp 1-47. http://ideas.repec.org/p/nbr/nberwo/16034 .html. Accessed 21 July 2013 
Kalemli-Ozcan S, Sorensen BE, Yosha O (2003) Risk sharing and industrial specialization: regional and international evidence. Am Econ Rev 93:903-918

Kalemli-Ozcan S, Sorensen BE, Yosha O (2004) Asymmetric shocks and risk sharing in a monetary union: updated evidence and policy implications for Europe. CEPR discussion papers 4463, pp 1-25. http://ideas.repec.org/p/cpr/ceprdp/4463.html. Accessed 15 Jan 2010

Keller W (2002a) Geographic localization of international technology diffusion. Am Econ Rev 92:120-142

Keller W (2002b) Trade and the transmission of technology. J Econ Growth 7:5-24

Klein MW, Olivei GP (2008) Capital account liberalization, financial depth, and economic growth. J Int Money Finance 27:861-875. https://doi.org/10.1016/j.jimonfin.2008.05.002

Kose MA, Prasad ES, Terrones ME (2006) How do trade and financial integration affect the relationship between growth and volatility? J Int Econ 69:176-202

Kose MA, Prasad E, Rogoff K, Wei SJ (2009a) Financial globalization: a reappraisal. IMF staff papers 56, pp 8-62. http://search.ebscohost.com/login.aspx?direct=true \&db=afh\&AN=37267779\&site=ehost -live

Kose MA, Prasad ES, Terrones ME (2009b) Does financial globalization promote risk sharing? J Dev Econ 89:258-270

Krugman P (1979) Increasing returns, monopolistic competition, and international trade. J Int Econ 9:469-479

Krugman P (1980) Scale economies, product differentiation, and the pattern of trade. Am Econ Rev 70:950-959

Krugman P (1991) Geography and trade. MIT Press, Cambridge

Krugman P, Venables AJ (1990) Integration and the competitveness of peripheral industry. CEPR discussion papers 363, pp 1-40. http://EconPapers.repec.org/RePEc:cpr:ceprdp:363

Lane PR, Milesi-Ferretti GM (2007) The external wealth of nations mark II: revised and extended estimates of foreign assets and liabilities, 1970-2004. J Int Econ 73:223-250

Levine R (1997) Financial development and economic growth: views and agenda. J Econ Lit 35:688-726

Longhi S, Nijkamp P, Traistaru I (2003) Determinants of manufacturing location in EU accession countries. European regional science association conference papers 310, pp 1-33. http://ideas.repec .org/p/wiw/wiwrsa/ersa03p310.html. Accessed 30 July 2010

Masten AB, Coricelli F, Masten I (2008) Non-linear growth effects of financial development: Does financial integration matter? J Int Money Finance 27:295-313

Melitz MJ (2003) The impact of trade on intra-industry reallocations and aggregate industry productivity. Econometrica 71:1695-1725

Moser G, Pointner W, Scharler J (2004) Risk sharing in Europe: Has anything changed? In: Liebscher K, Christl J, Mooslechner P, Ritzberger-Grunwald D (eds) The economic potential of a larger Europe. Edward Elgar Publishing, Cheltenham, pp 260-275

Nicita A, Olarreaga M (2007) Trade, production and protection 1976-2004. World Bank Econ Rev 21:165-171

Obstfeld M (1994) Risk-taking, global diversification, and growth. Am Econ Rev 84:1310-1329

Ohlin B (1933) Interregional and international trade. Harvard University Press, Cambridge

Ozer-Balli H, Sorensen BE (2010) Interaction effects in econometrics. CEPR discussion papers 7929, pp 1-34. http://ideas.repec.org/p/cpr/ceprdp/7929.html. Accessed 20 Jan 2012

Papageorgiou C, Savvides A, Zachariadis M (2007) International medical technology diffusion. J Int Econ 72:409-427

Pavcnik N (2002) Trade liberalization, exit, and productivity improvement: evidence from Chilean plants. Rev Econ Stud 69:245-76

Ricardo D (1817) On the principles of political economy and taxation. John Murray, London

Riet Av, Ernst E, Madaschi C, Orlandi F, Rivera AS, Robert B, Dópke J, Backinezos C, Bardakas I, Mora EG, Christian B (2004) Sectoral specialisation in the EU a macroeconomic perspective. ECB occasional paper series 19, pp 1-59. http://ideas.repec.org/p/ecb/ecbops/20040019.html. Accessed 20 June 2011

Rogoff K (1999) International institutions for reducing global financial instability. J Econ Perspect $13: 21-42$

Saint-Paul G (1992) Technological choice, financial markets and economic development. Eur Econ Rev 36:763-781

Sapir A (1996) The effects of Europe's internal market program on production and trade: a first assessment. Rev World Econ (Weltwirtschaftliches Archiv) 132:457-475 
Schiantarelli F, Sembenelli A (2000) Form of ownership and financial constraints: panel data evidence from flow of funds and investment equations. Empirica 27:175-192. https://doi. org/10.1023/A:1026588619191

Sorensen BE, Wu YT, Yosha O, Zhu Y (2007) Home bias and international risk sharing: twin puzzles separated at birth. J Int Money Finance 26:587-605

Trefler D (1993) International factor price differences: Leontief was right!. J Polit Econ 101:961-987

Trefler D (2004) The long and short of the Canadian-U.S. free trade agreement. Am Econ Rev 94:870-895

Venables AJ (1996) Equilibrium locations of vertically linked industries. Int Econ Rev 37:341-59

Publisher's Note Springer Nature remains neutral with regard to jurisdictional claims in published maps and institutional affiliations. 